\title{
Sustainability Assessment of Smallholder Farms in the Savannah Transition Agro-Ecological Zone of Ghana
}

\author{
Johnny Kofi Awoonor1, Edward Yeboah², Bright Fafali Dogbey³, Fowzia Adiyah4 \\ ${ }^{1}$ Soil Genesis, Survey and Classification Division, CSIR-Soil Research Institute, Kumasi, Ghana \\ ${ }^{2}$ Soil Microbiology Division, CSIR-Soil Research Institute, Kumasi, Ghana \\ ${ }^{3}$ Department of Soil Resources Management, CSIR College of Science and Technology, Accra, Ghana \\ ${ }^{4}$ Department of Soil Science, Szent István University, Gödöllő, Hungary \\ Email: johnnyawoonor@gmail.com
}

How to cite this paper: Awoonor, J.K., Yeboah, E., Dogbey, B.F. and Adiyah, F. (2021) Sustainability Assessment of Smallholder Farms in the Savannah Transition Agro-Ecological Zone of Ghana. Agricultural Sciences, 12, 1185-1214.

https://doi.org/10.4236/as.2021.1211076

Received: October 10, 2021

Accepted: November 6, 2021

Published: November 9, 2021

Copyright (c) 2021 by author(s) and Scientific Research Publishing Inc. This work is licensed under the Creative Commons Attribution International License (CC BY 4.0).

http://creativecommons.org/licenses/by/4.0/

\begin{abstract}
The ever-increasing human population has resulted in political pressure to increase crop production. Currently, smallholder farmers are expected to be environmentally considerate, adapt to extreme climatic conditions and deal with financial instability. Despite these recent developments, farmers and their farming activities in these rural environs of developing countries need to improve household food and income security on a sustainable basis. A minimum data set selected from extensive data was used to determine indicators for soil sustainability assessment. This method involved expert opinion and statistical data reduction techniques. The results indicated that SOC, MBC, BS, EC, Spo and sand were the most important variables selected as MDS using PC analysis. Forest and Grassland had a high sustainability index (SI) while Savannah woodland, Fallow and Cropland were rated not sustainable (NS). For Cumulative rating using the total dataset (CR-TDS), Forest had a high sustainability index (HS), Savannah woodland and Grassland were sustainable (S) compared to Fallow and Cropland, which were sustainable with high input (SWHI). Also, for cumulative rating using the minimum dataset (CR-MDS), Forest, Savannah woodland and Grassland had high sustainability $(\mathrm{SH})$ indices compared to Fallow and Cropland, which were considered sustainable with high input (SWHI). Sustainability index (SI) and Cumulative rating (CR) using the total dataset (CR-TDS) had a strong correlation $\left(\mathrm{R}^{2}=\right.$ $0.91, \mathrm{p}<0.05)$ compared to SI versus CR-MDS $\left(\mathrm{R}^{2}=0.44, \mathrm{p}<0.05\right)$ and CR-TDS versus CR-MDS $\left(\mathrm{R}^{2}=0.60, \mathrm{p}<0.05\right)$. These methods consider that these management goals dictate soil functions affecting the selection of indicators. Using PCA and variance analysis, silt, clay, EC, SOC, MBC and CEC
\end{abstract}


relating to soil texture and fertility were identified as the most influential (sensitive) indicators for soil sustainability assessment. The selected soil attributes can serve as target indicators for soil fertility restoration, erosion control and management in the Nkoranza district. Therefore, a farm-level sustainability index for small-scale and commercial farms is proposed based on readily available data for the Savannah Transition Agro-ecozone of Ghana.

\section{Keywords}

Sustainability, Land Use, Principal Component Analysis, Sustainability Index, Smallholder Farms

\section{Introduction}

The demand for crop production is increasing globally. This trend may continue for decades, resulting in the expansion of agricultural lands driven by a 2.3 billion increase in world population [1] [2]. In sub-Saharan Africa (SSA), the demand for food-crop production is expected to increase by 2050. This impact is associated with extensive land clearing and intensive use of existing croplands [3]. This has a local, regional and global environmental impact and implies that the preparation of smallholder farmlands in rural environments leads to habitat fragmentation, threatening biodiversity [4]. Understanding the future of crop production and how to increase yield with lower impacts require qualitative and quantitative assessments of future food demand. Therefore, the concept of sustainability is increasingly influencing agricultural policy [5]. The Food and Agriculture Organization (FAO) defines sustainable agriculture as "development that meets the needs of current generations without threatening the future generations' ability to meet their needs and aspirations" [6]. However, according to Frater and Franks (2013) [7], sustainable development distributes natural resources spatially and temporally.

Smallholder farmers in developing countries are expected to cultivate more food with limited resources without depleting the soil, which forms the foundation for human survival. These small family farm owners are critical to the management of soil resources [8], and the environment (SDG \#12, \#13 and \#15) can serve as the basis for poverty reduction (SDG \#1 and \#8), alleviation of hunger and malnutrition (SDG \#1 and \#2) and a reduction in food importation to promote food security and sustainability of agricultural production systems. The management of agroecosystems sustainably mostly involves many inputs (economic, social and environmental goals) that require increased input in sustainable management of soil resources on smallholder farms [9] [10]. Sustainability assessment of agricultural farms is faced with balancing optimum resource use and management of limited resources that can increase food production, economic growth, and environmental benefits to farmers in their communities [11] 
[12]. However, the long-term effect of agricultural sustainability can be measured. The measurement of long-term agricultural sustainability can result in economic and environmental benefits to small farm holders and can be monitored and documented for informed policy decisions [13]. Bechini and Castoldi (2009) [14] and Abraham and Pingali (2020) [15] stressed that the management of small farms sustainably is the remedy to address poverty, hunger and malnutrition among rural populations in developing countries of sub-Saharan Africa.

With increasing political pressure from governments to produce more food and be environmentally considerate in a changing world climate with extremes, coupled with financial instability, farming and its related activities need to become more sustainable [16]. To understand, monitor and improve agricultural sustainability, smallholder farmers will need additional tools to illustrate the impact of their business decisions in the Nkoranza District of Ghana [7]. However, existing tools to monitor and evaluate agricultural production systems' sustainability require the measurement of readily available variables. Most often, the formulation of these tools excludes farmers in their development and interpretation processes. Soil quality is considered an important component of sustainable agriculture [17] [18]. Most often, sustainability issues are much more extensive than soil quality and/or soil health assessment. There is a strong emphasis on maintaining the natural resource base to ensure that healthy soils are integral to sustainable agriculture [19]. Agricultural production systems at the farm level are sustainable if it conserves the natural resource of farms and satisfies the farm manager's needs overtime on issues that confront a farmer's productivity, stability, profitability, social and cultural acceptability.

There are several techniques to calculate the sustainability of a production system. For example, Ghaemi et al. (2014) [20] indicated that PCA, a multivariate statistical method increases the efficiency of the cumulative rating approach (CRA) to sustainability assessment in an agricultural system. The authors stressed that PCA is a suitable method for selecting operative indicators that play a significant role in soil sustainability assessment. Furthermore, Gomez et al. (1996) [21] introduced the sustainability index (SI) approach to assess the sustainability of soils in different agricultural management systems. On the other hand, the cumulative rating (CR) approach by Shukla et al. (2004) [22] uses critical levels which are classified into no limitation to an extreme limitation on a scale of 1- to 5 using a relative weighting factor (RWF) based on selected physico-chemical and biological properties of soil. Some authors use both methods, thus sustainability index and cumulative rating approach for sustainability assessment [23]. However, an agricultural production system [24] can be assessed by evaluating chronological changes using the sustainability index approach [25].

The objectives of this study were to: 1 ) assess the sustainability of the land-use systems identified, 2) select representative soil indicators using principal component analysis as pre-defined soil indicators, 3 ) assess the sensitivity of these 
systems, and (iv) determine the efficiency of the method adopted in sustainability assessment on small family farms for long-term maize cultivation in the Nkoranza District of Ghana's Forest Savannah Transition Agro-ecological zone.

\section{Materials and Methods}

\subsection{Study Area}

The study was conducted in Nkoranza North and South Districts. Nkoranza (North and South) District is bound by latitude $7^{\circ} 20^{\prime} \mathrm{N} \& 7^{\circ} 55^{\prime} \mathrm{N}$, and longitude $1^{\circ} 10^{\prime} \mathrm{W} \& 1^{\circ} 55^{\prime} \mathrm{W}$. These two districts were strategically selected for this study because they serve as important maize growing zone in Ghana. Also, the two districts (North and South) have about $80.9 \%$ and $92 \%$ of their rural households engaged in agriculture, respectively [26] [27]. The agricultural sector employs about 71 percent of the total working population [27]. Commerce, industry, and the service sector account for the remaining 29\% [28]. According to the updated Koppen-Geiger Climate Classification, the study area has a tropical savanna wet (Aw) climatic regime [29]. Annual rainfall ranges from 1200 to $1600 \mathrm{~mm}$. The rainfall pattern is bimodal, with an annual average of about $1350 \mathrm{~mm}$. The temperature in the study area is high throughout the year, with a maximum of 33 degrees Celsius and a minimum of 20 degrees Celsius [30] [31]. Annual evapotranspiration is approximately $1400 \mathrm{~mm}$, with actual evapotranspiration being approximately $1200 \mathrm{~mm}$ [32]. In the rainy season, relative humidity ranges from $90 \%$ to $95 \%$ and ranges from $75 \%$ to $80 \%$ in the dry season, respectively [31] [33].

The study area is undulating with a gradient of about $0.5 \%$ to $5 \%$. The northern half is undulating and flat, with elevations ranging from 150 - 300 metres [34]. The Voltain Sandstone Basin covers the study area. Sedimentary rocks, mostly fine-grained sandstone, massive, thin-bedded, flaky, ferruginous felspathic, and interbedded with shale and mudstone, make up the underlying geology [35]. These sedimentary strata represent the Davonian or early Carboniferous epoch [36]. Acrisols, fluvisols, gleysols, leptosols, lixisols, luvisols, and plinthosols according to the FAO-WRB Classification system, these soils predominate in Nkoranza (North and South) district (IUSS working group WRB, 2015) [37]. Distinct hydrological conditions along slopes have resulted in the formation of different soils from upland to lowland, resulting in numerous soil associations (such as Kpelesawgu-changnalili, Damongo-murugu, Bediase-sutawa, and Ejura-sene soil associations) [38]. These soils are often well-drained, deep, light-coloured, aerated, and organically rich in nutrients. In addition, they have a great water retention capacity, making it simple to grow food and cash crops. According to Asiamah (2008) [39], intense human activities like fuelwood harvesting, charcoal making, agriculture, settlement, lumbering, and annual bushfires have destroyed the natural forest. As a result, some of the original climax vegetation has survived. The main tree species include Afzelia Africana, Anogeissus leiocarpus, Borassus aetiopum, Butyrospermum partii, Parkia clappertoniana and Lophira alata. Brand 
and Brammer (1956) [40] described grass species as Andropogon gayanus, Imperata cylindrical, and Pennisetum purpureum.

\subsection{Soil Sampling}

A total of eighty (80) soil samples were collected in the Nkoranza (North and South) District. These soils were sampled from five (5) land-use systems. The soil core was sampled at two depths $(0-20 \mathrm{~cm} \mathrm{\&} 20-50 \mathrm{~cm})$. The soil sampling depth of $0-20 \mathrm{~cm}$ was used to represent the average cropland plough layer, and the $20-50 \mathrm{~cm}$ depth constitutes the average depth for plant nutrients and clay particles in an area with high rainfall. The soil sampling protocol designed by the World Agroforestry Centre (ICRAF) was adopted. ICRAF adopted the Land Degradation Surveillance Framework (LDSF) of the African Soil Information Service (AfSiS) sampling method to fit the smallholder farmers' farm structure (ranges from 1 - 10 acres). A marked rope was used and placing the actual sampling locations at the specified distance of 12.2 meters from the centre of sub-plot 1 in order to obtain a composite sample for the location [41] [42] (Figure 1). At a distance of 12.2 metres from the centre point (sub-plot 1) up-slope, sub-plot 2 was marked. Sub-plots 3 and 4 were offset at 120 and 240 degrees down-slope, respectively. A marked soil auger was used at each location to collect soil samples in the $20 \mathrm{~cm}$ depth in subplots 1, 2, 3 and 4 (Figure 1).

The reason for using this particular sampling pattern was to obtain composite samples representing a $1000 \mathrm{~m}^{2}$ area. A handheld GPS was used to record the longitudes and latitudes of each sampling site. Land use types were identified for each sampled site. The land-use types are shown in Table 1. An auger was used to collect soil samples at each location. Soil cores $(5 \mathrm{~cm}$ diameter) were obtained at each inspection location to identify and describe the soil type. The Visual Evaluation of Soil Structure (VESS) was used to assess the physical characteristics of soil structure. Soil depth, texture, drainage, and coarse fragments (gravels

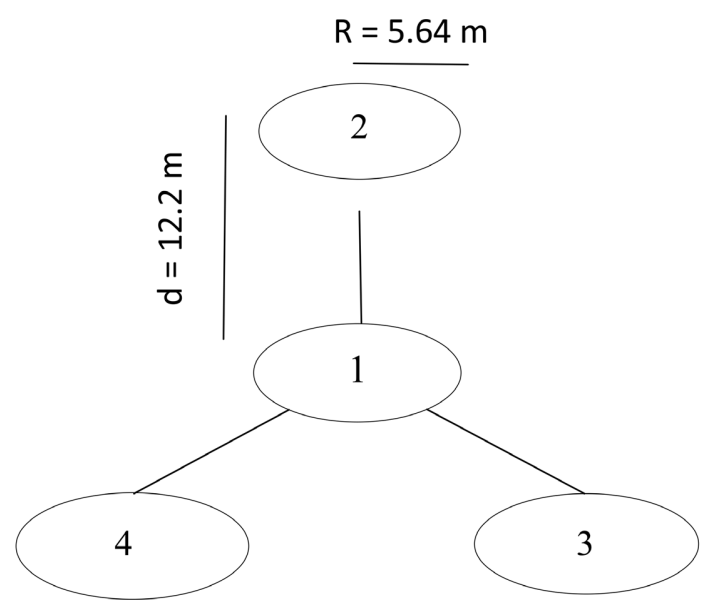

Figure 1. Illustrates soil sampling layout. Figures 1, 2, 3 and 4 indicate sampling sub-plots. Also, $\mathrm{d}$ is the distance between sub-plots centre points, and $\mathrm{R}$ is the sub-plot radius [43]. 
Table 1. Land use types identified in the study area.

\begin{tabular}{cccc}
\hline Land use & Symbol & Number of sampling sites & $\begin{array}{c}\text { Mean depth } \\
\text { of soil samples (cm) }\end{array}$ \\
\hline Forest & Fo & 6 & 221 \\
Savannah Woodland & SWL & 12 & 179 \\
Grassland & GL & 14 & 98 \\
Fallow & Fa & 22 & 155 \\
Cropland (maize fields) & CL & 26 & 181 \\
\hline
\end{tabular}

and stones), among other factors, were assessed on the field to classify soil types according to the local classification system [44]. Also, the soils were reclassified based on the FAO-WRB classification system [37]. The interpretation of soil data or soil quality indices requires some standard for comparison. These standards are necessary to assess whether a measured value or index is desirable and whether a given soil within a land-use system can be changed using sustainable management practices. Soils sampled from arable lands were compared with naturally-forested soils where the cycle and ecosystem were fundamentally different.

\subsection{Determination of Physico-Chemical and Biological Properties}

Standard procedures were used to determine the physico-chemical parameters of the sampled soils as follows: Soil moisture [45], bulk density [46], soil particle size distribution [47], $\mathrm{pH}$ in 1:2.5 soil/water suspension by $\mathrm{pH}$-meter [48], soil organic carbon (SOC) content by the Walkley-Black combustion method [49], and conversions between values of organic carbon and organic matter determined using Van Bemmelen factor of 1.724 on the assumption that, on average, soil organic matter contains $58 \%$ of soil organic $\mathrm{C}$, total nitrogen by the Kjeldahl method [50] and available P by the method of Olsen et al. (1954) [51]. With $1 \mathrm{M}$ $\mathrm{NH}_{4} \mathrm{OAC}(\mathrm{pH}$ 7.0), exchangeable bases were extracted to determine $\mathrm{K}$ and $\mathrm{Na}$ using a flame photometer and exchangeable $\mathrm{Mg}$ and $\mathrm{Ca}$ using an atomic absorption spectrophotometer [52]. Cation exchange capacity (CEC) was determined by ion extraction with ammonium acetate solution and subsequent determination of the extracted cations [53]. The ratio of basic cations in CEC was used to determine base saturation (BS). In addition, microbial biomass C (MBC) [54] was determined.

\subsection{Indicator Selection}

The authors compared expert opinion (EO) and principal component analysis, the two most frequently used methods for MDS selection (multivariate data reduction technique). Soil data from several land-use systems were used to compare MDS results. Principal components are linear combinations of the variables that account for maximum variance in a data set. Dunteman (1989) [55] de- 
scribed these as "vectors of closest fit to the $\mathrm{n}$ observation in a p-dimensional space" subject to being orthogonal to each other. There are several documented strategies for selecting a subset from a large data set using PCA. The one discussed here is similar to Dunteman's (1989) [55]. All (untransformed) data were subjected to a standardised PCA, revealing statistically significant variations between management systems. The assumption is that the PCs with the highest eigenvalues best represent system variance. As a result, only PCs with eigenvalues less than one [56] were considered. Furthermore, according to Wander and Bollero (1999) [57], PCs that explained less than $5 \%$ of the variability in the data were included if the Eigenvalues were less than 1. Each variable in a PC is assigned a weight or factor loading. A factor loading represents the contribution of that variable to a PC's composition.

According to Wander and Bollero (1999) [57], the highest weighted factor loadings were defined as having absolute values within $15 \%$ of the highest factor loading or $\geq 0.40$, where more than one factor was retained under a PC. A multivariate correlation co-efficient analysis was employed to determine if the variable could be considered redundant or eliminated from the MDS [9]. Also, if highly weighted factors correlate $(>0.60)$, then each was considered important and retained in the MDS. The variable with the highest factor loading was selected for the MDS from a list of well-considered variables. After selecting MDS indicators, correlations among PC indicators led to selecting one replacement indicator for an indicator pair with correlation coefficients $\geq 0.70$. Also, the management goal variable was the dependent variable in multiple regressions using the EO selected and PCA-MDS techniques. The MDS functioned as the independent variable, whereas each management variable functioned as the dependent variable [9] [58] [59]. The cumulative rating approach was made more efficient by using principal component analysis. It requires less soil data to assess a land-use system's long-term sustainability. This statistical reduction technique is appropriate for identifying more effective indicators important for agriculture and/or soil sustainability assessment.

\subsection{Sustainability Assessment}

\subsubsection{Sustainability Index (SI) Approach}

The sustainability of an agricultural production system [24] can be assessed by evaluating temporal changes using the sustainability index approach [25]. Based on this, the sustainability of soil quality values was assessed to ascertain if current soil quality can be improved and sustained within land-use systems in the Nkoranza (North and South) District. Each soil indicator chosen for sustainability assessment was given a relative weighting factor (range from 1 to 5 ) depending on their critical levels (Table 2).

The use of threshold levels [21] for sustainability indicators linked to soil physical, chemical, and biological quality was computed. Sustainability indices were calculated by dividing the soil physico-chemical parameters (indicators) by 
a Gomez et al. (1996) [21] defined threshold value. On the other hand, the threshold values were divided by the actual bulk density values of the soil (Table 3 ). The importance of an indicator in enhancing the sustainability of a land-use system is indicated by its relative weighting factor. In the sustainability index approach, a value of one or more parameters indicates a positive contribution to an agricultural system. However, a value of less than one indicates the high sustainability of an agricultural production system (Table 4). The "less is better" system of sustainability rating was adopted from Lal (1994) [60]. The sustainability rating of land use was based on eleven (11) soil indicators. Also, the relative weighting of sustainability indicators for the five land-use types was computed.

Table 2. Limitation ranges with relative weighting factors (RWF).

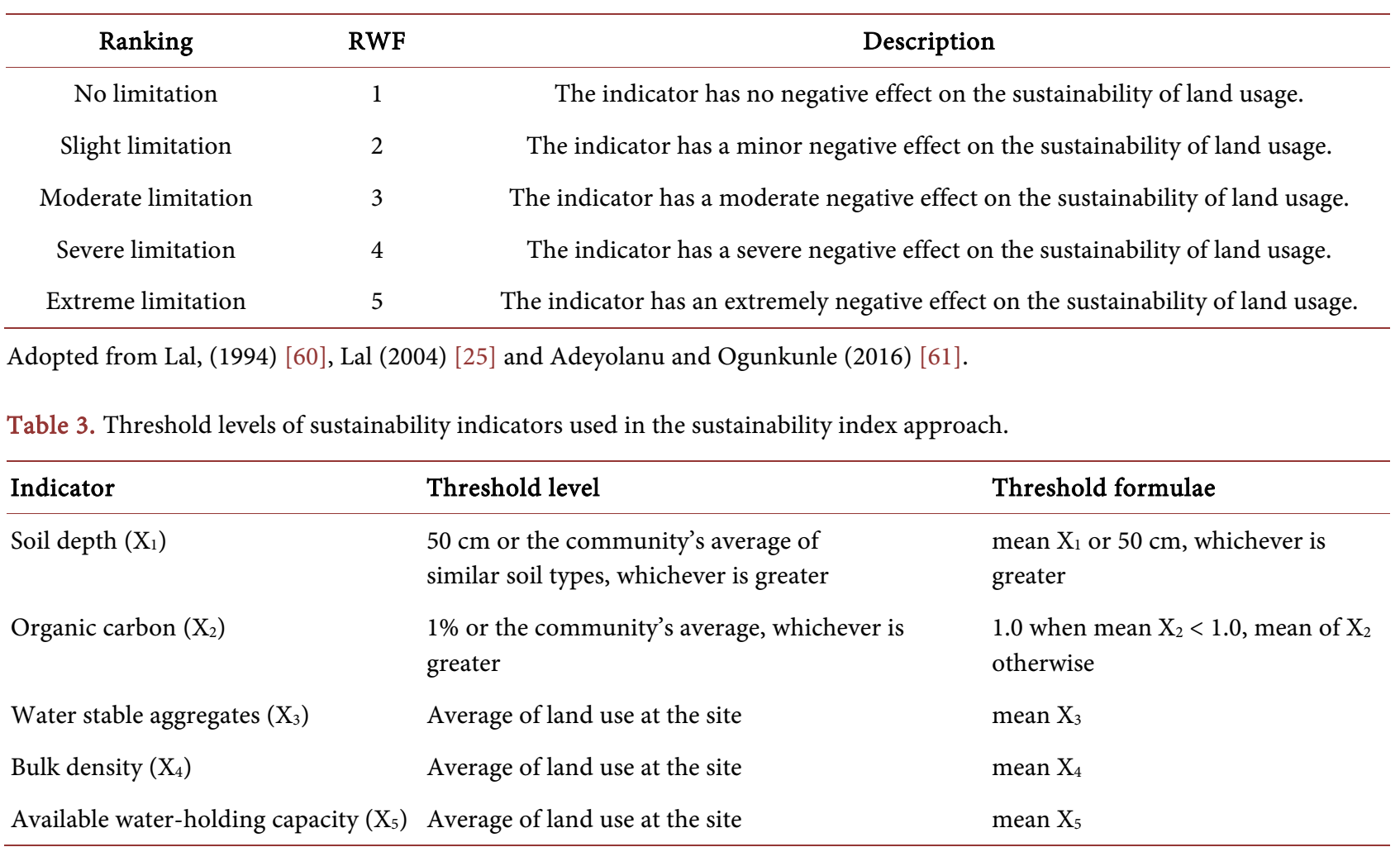

Source: Lal (1994) [60]; Singh and Khera (2009) [23].

Table 4. Sustainability rating of land use based on less is a better approach in relation to the cumulative rating (CR) index.

\begin{tabular}{ccc}
\hline Sustainability rating & Cumulative Rating (CR) & Relative Weighting Factor (RWF) \\
\hline Highly sustainable (HS) & $<20$ & 1.00 \\
Sustainable (S) & $20-25$ & 3.00 \\
Sustainable with high input (SWHI) & $25-30$ & 4.00 \\
Sustainable with another land use (SWALU) & $30-40$ & 5.00 \\
\hline Unsustainable (US) & $>40$ & \\
\hline
\end{tabular}

Source: Lal (1994) [60]. 
Finally, sustainability indices were calculated for the identified land-use systems (forest, savannah woodland, Grassland, fallow and cropland), and the relationship between soil quality and sustainability was established using regression analysis.

\subsubsection{Cumulative Rating (CR) Approach}

Critical limits were used as a reference in the cumulative rating method [60]. Critical levels based on limitations to crop production systems were assigned. As shown in Table 5 and Table 6, these critical values ranged from no constraints to high limitations on a scale of 1 to 5, as Shukla et al. (2004) [22] described for the relative weighting factor. Land use or soil property with a low limit of one indicated outstanding soil quality (no limitation). An upper limit of five or extreme, on the other hand, indicates severe limitation or restraint. The cumulative rating (Table 5 and Table 6 ) for a production system was used to measure the soil sustainability of an agricultural system, which varied from very sustainable $(\mathrm{CR}<20)$ to unsustainable $(\mathrm{CR}>40)$.

\subsection{Statistical Analysis}

Descriptive statistics for soil properties in land-use types were computed. Basic statistics calculated include minimum, maximum, mean, standard deviation, coefficient of variation, skewness and kurtosis. In addition, the Pearson correlation

Table 5. Critical levels and relative weighting factors for soil physico-chemical properties used in the cumulative rating approach.

\begin{tabular}{cccccccc}
\hline Limitation & RWF & Texture & BD & Spo & AWHC & Gco & SHC \\
\hline None & 1 & Loam & $<1.30$ & $>20.00$ & $>30.00$ & $<10.00$ & $>2.00$ \\
Slight & 2 & SiL, Si, SiCL & $1.30-1.40$ & $18.00-20.00$ & $20.00-30.00$ & $10.00-20.00$ & $0.20-2.00$ \\
Moderate & 3 & CL, SL & $1.40-1.50$ & $15.00-18.00$ & $8.00-20.00$ & $20.00-40.00$ & $0.02-0.020$ \\
Severe & 4 & SiC, LS & $1.50-1.60$ & $10.00-15.00$ & $2.00-8.00$ & $40.00-60$ & $0.002-0.02$ \\
Extreme & 5 & C, S & $>1.60$ & $<10.00$ & $<2$ & $>60$ & $>0.002$ \\
\hline
\end{tabular}

Source: Lal (1994) [60]. Abbreviation: BD, bulk density (g/cm³); Spo, soil porosity (\%); Gco, gravel content (\%); SHC, saturated hydraulic conductivity (cm/hr); AWHC, available water holding capacity (\%); RWF, Relative Weighting Factor.

Table 6. Critical levels and relative weighting factors for soil physical and chemical properties used in the cumulative rating approach.

\begin{tabular}{ccccccc}
\hline Limitation & RWF & CEC & SOC & MBC & pH & EC \\
\hline None & 1 & $<5.00$ & $5.00-10.00$ & $>25.00$ & $6-7$ & $3.00-5.00$ \\
Slight & 2 & $5.00-10.00$ & $3.00-5.00$ & $20.00-25.00$ & $5.80-6.00 \& 7.00-7.40$ & $5.00-7.00$ \\
Moderate & 3 & $10.00-15.00$ & $1.00-3.00$ & $10.00-20.00$ & $5.40-5.80 \& 7.40-7.80$ & $5.00-10.00$ \\
Severe & 4 & $15.00-20.00$ & $0.50-1.00$ & $5.00-10.00$ & $5.00-5.40 \& 7.80-8.20$ & $<5.00 \&>8.20$
\end{tabular}

Source: Lal (1994) [60]. Abbreviation: SOC, soil organic carbon (\%); MBC, microbial biomass carbon (mg/kg); CEC, cation exchange capacity $\left(\mathrm{cmol}_{(+)} / \mathrm{kg}\right) ; \mathrm{pH}$, soil pH (1:2.5); EC, electrical conductivity $(\mathrm{dS} / \mathrm{m})$; RWF, Relative Weighting Factor. 
coefficient (two-tailed) was tabulated for soil properties to create a correlation matrix table. Also, descriptive and inferential analyses were conducted to compare the means of selected soil properties for the MDS. Also, PCA of soil properties assisted in identifying soil properties sensitive to soil management and serves as an indicator of agricultural sustainability. Normality in the data set was determined using skewness, kurtosis and Kolmogorov Smirnov (K-S) test. Coefficient of variation (CV), an important and mostly used dimensionless index, was used to indicate the variability within variables.

Using Nielsen and Bouma's (1985) [62] rating, coefficient of variation was classified as CV $\leq 10,10 \% \leq 100 \%$, and CV $>100 \%$ indicated a weak, moderate and strong variability, respectively. Also, Pearson correlation and regression analysis were used to assess the relationships between soil properties and land use types. Analysis of variance (ANOVA) and the least significant difference (LSD) tests was computed to determine the significant difference between soil properties and land use types [63]. Although, statistically, differences were considered significant at the $\mathrm{p}<0.05$ level., soil attributes relating to soil function and are sensitive to change in land use were computed using analysis of variance. The sensitivity of a land-use reflects in soil attribute variability among land-use types. The coefficient of variation and the ratio of range and mean (Relative Ratio) were used to determine the sensitivity of these indicators in the five identified land-use systems. A CV range between 0 - 10, 10 - 40, 40 - 100 and $>100$ was rated as no sensitivity, low, moderate and high sensitivity, respectively. Soil indicators with a high CV and RR indicate an indicator's sensitivity to land-use changes [64]. All statistical analyses were performed using GenStat (version 12) and IBM SPSS version 20 (SPSS Inc., Chicago, USA).

\section{Results}

The sustainability of smallholder maize farms on cropland and identified land-use systems (Table 7) were assessed in the Nkoranza District. Linear scoring of soil properties was carried out by indexing. The soils of the district were generally deep on the upper, middle and lower slopes. Soil depth varied from 7 $\mathrm{cm}$ (Changnalili series: Gleyic Plinthosol) to $215 \mathrm{~cm}$ (Bediesi series: Dystric Nitisol) in the study area. Also, soil texture varied from loamy sand to clay loam in the top and subsoil. The soils: Damongo (Rhodic Luvisol), Murugu (Haplic Luvisol), Bediesi (Dystric Nitisol), Sutawa (Plinthic Luvisol), and Tanoso (Dystric Gleysol) series were formed from sandstone, while Kpelesawgu (Dystric Plinthosol) and Changnalili (Gleyic Plinthosol) series were formed from shale and colluvium (sediments). As a result, the depth distribution of soil properties was irregular, and sandy layers observed in sub-surface layers enhanced the leaching of soil nutrients.

\subsection{Descriptive Statistics of Soil Properties (0 - $20 \mathrm{~cm})$}

Physically, clay content ranged from $7.78 \%$ to $33.24 \%$ (Table 8). Percentage clay 
Table 7. Description of land use systems identified in the Nkoranza District.

\begin{tabular}{|c|c|}
\hline Land use & Description \\
\hline Forest (Fo) & Less disturbed land covered with tall and dense trees. This system consists of native tree species and vegetation. \\
\hline Savannah & Savannah vegetation mixed with woodland and grassland ecosystem. It is characterised by trees widely spaced. \\
\hline woodland (SWL) & Sufficient sunlight reaches the ground gave rise to a micro-climate that supports grasses. \\
\hline Grassland (GL) & $\begin{array}{l}\text { Rolling terrain with grasses. The local climate favours the growth of these grasses and, in some cases, a few } \\
\text { trees. }\end{array}$ \\
\hline Fallow $(\mathrm{Fa})$ & Abandoned land left to recover its fertility. \\
\hline Cropland (CL) & $\begin{array}{l}\text { The land was cropped to maize continuously. Continuous clearing, removal of above-ground biomass (crop } \\
\text { residue) and levelling of farm fields resulted in a land-use change (information from local farmers). The use of } \\
\text { manure and fertiliser was low on some farms. }\end{array}$ \\
\hline
\end{tabular}

Source: Tan et al. (2009) [65].

Table 8. Descriptive statistics of soil properties $(0-20 \mathrm{~cm})$ in the study area.

\begin{tabular}{ccccccccc}
\hline Variance & Min & Max & Mean & SD & Variance & CV (\%) & Kurtosis & Skewness \\
\hline Sand & 40.40 & 84.04 & 64.97 & 13.26 & 175.90 & 20.42 & -1.17 & -0.45 \\
Silt & 3.72 & 32.36 & 17.55 & 8.88 & 78.99 & 50.65 & -1.15 & 0.22 \\
Clay & 7.78 & 33.24 & 17.48 & 7.30 & 53.31 & 57.09 & -0.63 & 0.56 \\
Spo & 32.45 & 66.11 & 49.19 & 11.71 & 137.1 & 23.81 & -1.38 & 0.99 \\
BD & 0.89 & 1.40 & 1.13 & 0.30 & 0.01 & 11.64 & -0.41 & -0.01 \\
AWHC & 13.80 & 33.70 & 21.26 & 5.63 & 31.79 & 26.52 & -0.62 & 0.54 \\
Gco & 0.00 & 54.74 & 15.48 & 2.23 & 450.00 & 37.19 & -1.06 & 0.80 \\
SHC & 0.08 & 0.28 & 0.17 & 0.04 & 0.00 & 25.03 & 0.87 & 0.64 \\
SOC & 0.17 & 2.53 & 1.06 & 0.64 & 0.41 & 60.32 & 0.11 & 0.98 \\
BS & 70.39 & 99.88 & 91.51 & 8.58 & 73.62 & 9.37 & -0.06 & -0.97 \\
CEC & 2.80 & 18.61 & 6.50 & 4.56 & 20.86 & 70.19 & 1.65 & 1.63 \\
pH & 3.90 & 7.50 & 5.70 & 1.07 & 1.14 & 18.75 & -1.07 & 0.07 \\
EC & 20.00 & 240.00 & 112.50 & 64.23 & 4125.00 & 41.76 & -0.72 & 0.53 \\
MBC & 3.37 & 209.50 & 77.30 & 7.07 & 4910.00 & 90.65 & -1.13 & 0.58 \\
\hline A & & 2.30 & &
\end{tabular}

Abbreviation: SOC, soil organic carbon (\%); BD, bulk density $\left(\mathrm{g} / \mathrm{cm}^{3}\right)$; BS, base saturation (\%); $\mathrm{MBC}$, microbial biomass carbon $(\mathrm{mg} / \mathrm{kg}) ; \mathrm{CEC}$, cation exchange capacity $\left(\mathrm{cmol}_{(+)} / \mathrm{kg}\right) ; \mathrm{pH}$, soil $\mathrm{pH}(1: 2.5)$; Spo, soil porosity (\%); Gco, gravel content (\%); EC, electrical conductivity $(\mathrm{dS} / \mathrm{m})$; SHC, saturated hydraulic conductivity $(\mathrm{cm} / \mathrm{hr}) ;$ AWHC, available water holding capacity $(\%)$, Sand (\%); Silt (\%); Clay (\%).

varied with forest (25.92\%), cropland (19.00\%), grassland (12.14\%), fallow (15.27\%) and savannah woodland (15.08\%) (Table 8 and Table 9). Percentage sand ranged from $40.4 \%$ to $84.04 \%$. Also, the percentage of sand followed the order: Grassland $<$ Fallow $<$ Cropland $<$ Savannah Woodland $<$ Forest. Thus Grassland, Fallow, Cropland, Savannah Woodland and Forest recorded 73.04\%, $70.14 \%, 68.27 \%, 67.69 \%$ and $45.72 \%$, respectively. For silt (\%), Forest recorded 
Table 9. Least Significant Difference (LSD) of soil properties.

\begin{tabular}{ccccc}
\hline Land use & Sand & Clay & Silt & Texture \\
\hline Forest & $45.72^{\mathrm{b}}$ & $25.92^{\mathrm{a}}$ & $28.36^{\mathrm{a}}$ & Loam \\
Savannah woodland & $67.69^{\mathrm{a}}$ & $15.08^{\mathrm{b}}$ & $17.23^{\mathrm{ab}}$ & Sandy Loam \\
Grassland & $73.04^{\mathrm{a}}$ & $12.14^{\mathrm{b}}$ & $14.82^{\mathrm{b}}$ & Sandy Loam \\
Fallow & $70.14^{\mathrm{a}}$ & $15.27^{\mathrm{b}}$ & $14.59^{\mathrm{b}}$ & Sandy Loam \\
Cropland & 68.27 & $19.00^{\mathrm{ab}}$ & $12.73^{\mathrm{b}}$ & Sandy Loam \\
Mean & 64.97 & 17.48 & 17.55 & 6.25 \\
SD & 10.96 & 5.31 &
\end{tabular}

Significant differences (LSD) among the different land-use types $(\mathrm{p}<0.05)$ are indicated by different letters.

28.36\%, followed by Savannah woodland (17.23\%), Grassland (14.82\%), Fallow (14.59\%) and Cropland (12.73\%). Soil porosity ranged from 32.45 to $69.11 \%$. For land-use systems, it followed the order: Forest $<$ Grassland $<$ Fallow $<$ Savannah Woodland $<$ Cropland, respectively (Table 9). Statistically, there was a significant difference between forest and the other land-use types for soil water holding capacity. Soil water holding capacity ranged from 13.80 to 33.70 , and within land-use types, Forest recorded 29.45, followed by Cropland (21.83), Fallow (19.48), Savannah woodland (18.30), and Grassland (17.43).

In comparison, soil hydraulic conductivity ranged from 0.08 to 0.28 . It followed the order in land use systems: Fallow < Forest $<$ Savannah Woodland < Grassland < Cropland. Bulk density ranged from 0.89 to $1.40 \mathrm{~g} / \mathrm{cm}^{3}$. For land-use systems, it followed the order: cropland $<$ Savannah Woodland $<$ Fallow $<$ Grassland < Forest thus $1.21 \mathrm{~g} / \mathrm{cm}^{3}, 1.18 \mathrm{~g} / \mathrm{cm}^{3}, 1.15 \mathrm{~g} / \mathrm{cm}^{3}, 1.11 \mathrm{~g} / \mathrm{cm}^{3}$ and $1.02 \mathrm{~g} / \mathrm{cm}^{3}$, respectively. Chemically, soil $\mathrm{pH}$ ranged from 3.9 to 7.50 , with a mean value of 5.70 (Table 8). Soil organic carbon in the study area ranged from $0.17 \%$ to $2.53 \%$, with a mean organic carbon (OC) content of $1.06 \%$ at the 0 to $20 \mathrm{~cm}$ soil surface layer. Cation exchange capacity (CEC) had a mean value of 6.50 $\mathrm{cmol}_{(+)} / \mathrm{kg}$ in surface layers (Table 10). The soils of forest had high CEC (14.10 $\left.\mathrm{cmol}_{(+)} / \mathrm{kg}\right)$, whereas soils of cropland recorded a low CEC $\left(4.17 \mathrm{cmol}_{(+)} / \mathrm{kg}\right)$.

For CEC, there was no statistical difference in land-use types $(\mathrm{p}=0.05)$. BS recorded range values between $70.39 \%$ and $99.88 \%$. For land-use systems, it followed the order: Forest $<$ Grassland $<$ Fallow $<$ Cropland $<$ Savannah Woodland (Table 10). Electrical conductivity within the topsoil ranged from 20 to 240. Within land-use, Forest, Fallow, Savannah woodland, Cropland and Grassland recorded 187.50, 110, 95, 92.50 and $77.50 \mathrm{dS} / \mathrm{m}$, respectively. Biologically, microbial biomass carbon (MBC) ranged from $3.37 \mathrm{mg} / \mathrm{kg}$ to $209 \mathrm{mg} / \mathrm{kg}$. Also, MBC varied significantly within land-use types. Forest, Savannah Woodland, Fallow, Grassland and Cropland recorded 158, 136.51, 60.73, 25.04 and 5.33 $\mathrm{mg} / \mathrm{kg}$, respectively. Statistically, a significant difference was observed between 
Table 10. Least significant difference (LSD) of soil properties.

\begin{tabular}{|c|c|c|c|c|c|c|c|c|c|c|c|}
\hline \multirow{2}{*}{ Land use } & \multicolumn{11}{|c|}{ Indicators } \\
\hline & Spo & $\mathrm{BD}$ & AWHC & Gco & SHC & SOC & BS & CEC & $\mathrm{pH}$ & EC & $\mathrm{MBC}$ \\
\hline Forest & $61.4^{\mathrm{a}}$ & $1.02^{\mathrm{a}}$ & $29.45^{\mathrm{a}}$ & $39.63^{a}$ & $0.18^{\mathrm{a}}$ & $2.18^{\mathrm{a}}$ & $99.00^{\mathrm{a}}$ & $14.10^{\mathrm{a}}$ & $6.55^{\mathrm{a}}$ & $187.50^{\mathrm{a}}$ & $158.00^{\mathrm{a}}$ \\
\hline Savannah & $39.77^{b}$ & $1.18^{\mathrm{a}}$ & $18.30^{\mathrm{b}}$ & $0.01^{\mathrm{b}}$ & $0.17^{\mathrm{a}}$ & $0.84^{\mathrm{b}}$ & $82.89 c$ & $4.15^{\mathrm{a}}$ & $4.80^{\mathrm{b}}$ & $95.00^{\mathrm{b}}$ & $136.51^{\mathrm{a}}$ \\
\hline Grassland & $57.05^{\mathrm{a}}$ & $1.11^{\mathrm{a}}$ & $17.43^{\mathrm{b}}$ & $37.77^{\mathrm{a}}$ & $0.16^{\mathrm{a}}$ & $0.88^{\mathrm{b}}$ & $95.64^{\mathrm{ab}}$ & $5.76^{\mathrm{a}}$ & $6.25^{\mathrm{a}}$ & $77.50^{\mathrm{b}}$ & $25.04^{\mathrm{b}}$ \\
\hline Fallow & $51.74^{\mathrm{a}}$ & $1.15^{\mathrm{a}}$ & $19.48^{\mathrm{b}}$ & $0.00^{\mathrm{b}}$ & $0.20^{\mathrm{a}}$ & $0.70^{\mathrm{b}}$ & $93.53^{\mathrm{b}} \mathrm{c}$ & $4.35^{\mathrm{a}}$ & $6.05^{\mathrm{ab}}$ & $110.00^{\mathrm{ab}}$ & $60.73^{\mathrm{b}}$ \\
\hline Cropland & $36.00^{\mathrm{b}}$ & $1.21^{\mathrm{a}}$ & $21.83^{\mathrm{b}}$ & $0.00^{\mathrm{b}}$ & $0.16^{\mathrm{a}}$ & $0.75^{\mathrm{b}}$ & $86.49^{\mathrm{b}} \mathrm{c}$ & $4.17^{\mathrm{a}}$ & $4.88^{\mathrm{b}}$ & $92.50^{\mathrm{b}}$ & $5.33^{\mathrm{b}}$ \\
\hline Mean & 49.19 & 1.13 & 21.30 & 15.48 & 0.17 & 1.07 & 91.51 & 6.51 & 5.71 & 112.50 & 77.12 \\
\hline Threshold & 49.19 & 1.13 & 21.30 & 15.48 & 0.17 & 1.00 & 91.51 & 6.51 & 5.71 & 112.50 & 77.12 \\
\hline SD & 10.96 & 0.07 & 4.85 & 2.21 & 0.02 & 0.62 & 6.65 & 4.30 & 0.81 & 43.48 & 67.46 \\
\hline
\end{tabular}

Abbreviation: SOC, soil organic carbon (\%); BD, bulk density $\left(\mathrm{g} / \mathrm{cm}^{3}\right)$; BS, base saturation (\%); $\mathrm{MBC}$, microbial biomass carbon $(\mathrm{mg} / \mathrm{kg})$; CEC, cation exchange capacity $\left(\mathrm{cmol}_{(+)} / \mathrm{kg}\right) ; \mathrm{pH}$, soil $\mathrm{pH}(1: 2.5)$; Spo, soil porosity (\%); Gco, gravel content (\%); EC, electrical conductivity $(\mathrm{dS} / \mathrm{m})$; SHC, saturated hydraulic conductivity $(\mathrm{cm} / \mathrm{hr}) ;$ AWHC, available water holding capacity (\%), Sand (\%); Silt (\%); Clay (\%). Significant differences (LSD) among the different land use types $(\mathrm{p}<0.05)$ are indicated by different letters.

Forest and the other land-use types for SOC, BS, pH, EC and MBC (Table 9 and Table 10). Also, among the eleven (11) soil indicators, silt, clay, SOC, CEC, EC and MBC had a moderate CV. However, sand, Spo, BD, AWHC, Gco, SHC, BS and $\mathrm{pH}$ had a low CV. From the above, silt, clay, SOC, CEC, EC and MBC were selected as indicators with high sensitivity to soil management.

\subsection{Principal Component Analysis (PCA) of Soil Properties}

The multivariate correlation matrix of soil properties for the 0 to $20 \mathrm{~cm}$ depth revealed several and similar sets of relationships. However, data on the $0-20 \mathrm{~cm}$ soil depth were presented in Table 11. The results obtained from the PCA revealed five (5) principal components from eleven (11) normalised soil properties. Also, a varimax rotation performed on the four (4) components explained $98.53 \%$ of the total variance for the $0-20 \mathrm{~cm}$ soil depths. This explained $98.53 \%$ of the variability in the dataset with eigenvalues greater than one (1) for PC 1 , PC 2, PC 3 and PC 4 (Table 11). Also, PCA assisted in identifying soil variables from each principal component $(\mathrm{PC})$ considered for the minimum dataset (MDS). The first PC explained $72.71 \%$ of the variance. The soil parameters with high positive loadings for PC1 are MBC (0.72) and EC (0.65). Correlation analysis between these parameters showed a significant positive correlation (0.72) between MBC and EC (Table 12). Furthermore, MBC and EC had high communality estimate values of 1.00 and 0.99 , respectively. This implies that PC 1 best explains the relationship between $\mathrm{MBC}$ and $\mathrm{EC}$. Soil $\mathrm{MBC}$ relates closely to some soil biological properties and processes.

For example, a common relationship between SOC or C inputs reflects the 
Table 11. Principal components, eigenvalues and component matrix variables.

\begin{tabular}{|c|c|c|c|c|c|}
\hline Principal components & PC 1 & PC 2 & PC 3 & PC 4 & Communalities \\
\hline Eigen values & 7.03 & 2.19 & 1.98 & 1.4 & \\
\hline Variance (\%) & 72.71 & 19.37 & 4.81 & 1.64 & \\
\hline $\mathrm{CV}(\%)$ & 72.71 & 92.08 & 96.89 & 98.53 & \\
\hline \multicolumn{6}{|c|}{ Factor loadings (Rotated component matrix) } \\
\hline Clay & 0.05 & 0.04 & 0.02 & 0.31 & 0.10 \\
\hline SOC & 0.06 & 0.80 & 0.10 & 0.01 & 0.72 \\
\hline Sand & -0.10 & -0.01 & -0.16 & -0.74 & 0.58 \\
\hline Silt & 0.05 & -0.02 & 0.14 & 0.42 & 0.20 \\
\hline Spo & 0.05 & 0.08 & 0.63 & -0.14 & 0.51 \\
\hline AWHC & 0.04 & 0.03 & 0.05 & 0.31 & 0.10 \\
\hline $\mathrm{BD}$ & 0.00 & 0.00 & 0.00 & 0.00 & 0.00 \\
\hline BS & 0.03 & 0.06 & 0.88 & 0.11 & 0.83 \\
\hline $\mathrm{MBC}$ & 0.74 & -0.66 & 0.01 & -0.08 & 1.00 \\
\hline CEC & 0.04 & 0.03 & 0.08 & 0.04 & 0.01 \\
\hline $\mathrm{EC}$ & 0.65 & 0.73 & -0.18 & -0.07 & 0.99 \\
\hline Gco & 0.07 & 0.11 & 0.20 & -0.21 & 0.05 \\
\hline $\mathrm{pH}$ & 0.00 & 0.01 & 0.02 & 0.01 & 0.00 \\
\hline SHC & 0.00 & 0.00 & 0.00 & 0.00 & 0.00 \\
\hline
\end{tabular}

Boldface factor loadings considered highly weighted were retained in the MDS [66]. Abbreviation: SOC, soil organic carbon (\%); $\mathrm{BD}$, bulk density $\left(\mathrm{g} / \mathrm{cm}^{3}\right)$; $\mathrm{BS}$, base saturation (\%); $\mathrm{MBC}$, microbial biomass carbon $(\mathrm{mg} / \mathrm{kg}) ; \mathrm{CEC}$, cation exchange capacity $\left(\mathrm{cmol}_{(+)} / \mathrm{kg}\right) ; \mathrm{pH}$, soil $\mathrm{pH}(1: 2.5)$; Spo, soil porosity $(\%)$; Gco, gravel content (\%); EC, electrical conductivity $(\mathrm{dS} / \mathrm{m})$; SHC, saturated hydraulic conductivity $(\mathrm{cm} / \mathrm{hr}) ; \mathrm{AWHC}$, available water holding capacity (\%), Sand (\%); Silt (\%); Clay (\%).

importance of substrate availability and input into the soil medium. These selected variables ( $\mathrm{MBC}$ and $\mathrm{EC}$ ) explain the microbial biomass management component of the soil. Hence, PC 1 could be referred to as the MBC factor. For PC 2, it explained $19.37 \%$ of the variance with positive loadings on SOC $(0.80)$ and EC (0.73), and a negative loading on MBC was observed for PC 2. Also, MBC partly belongs to PC 2 with a negative loading of -0.66 (Table 12). Therefore, the loadings of SOC, MBC and EC on this PC indicated EC's influence on SOC. However, MBC and EC had a common variance because their concentration in the soil was influenced by the amount of SOC which plays a crucial role in improving soil nutrients. The elements loaded in PC 2 help explain soil fertility and soil-plant nutrient cycling and management. Therefore, these selected variables explain the fertility component, and PC 2 could be termed the SOC factor. 
Correlation analysis indicated a significant positive correlation (0.64) between SOC and EC. Also, PC 3 and PC 4 explained $4.81 \%$ and $1.64 \%$ of the variability in the dataset. For PC 3, BS (0.88) and Spo (0.63) were highly weighted, and correlation analysis between BS and Spo revealed a significant positive correlation (0.80). Communality estimates (CE) showed that this PC explained $83 \%$ of the variability in BS and more than $50 \%$ in Spo. Sand $(-0.74)$ had a highly significant negative loading on PC4 (Table 11). The CE indicated that PC 4 explained $58 \%$ of the variability in sand. Sand plays an important role in influencing soil physical properties such as clay and silt, and these possess the capacity to store and release soil nutrients to plants. Also, sand influences water movement in the soil medium and could be termed the soil textural factor. From Table 11, the negative loadings on sand imply that soils with high sand content generally have low SOM content. These selected variables were retained in the MDS because they were the highly weighted parameters.

\subsection{Correlation Analysis}

Pearson correction values $>0.60$ between physicochemical and biological properties indicate that most of the indicators positively correlated with each other (Table 12). Soil organic carbon (OC) positively correlated with CEC (0.87) and EC (0.64). Silt correlated positively with AWHC (0.62), and AWHC correlated with clay (0.91). Also, BS positively correlates with $\mathrm{pH}(0.90)$. There was a significant positive correlation between CEC and SOC (0.87) and AWHC (0.65). Also, gravel content (Gco) correlated positively with Spo (0.64) and CEC (0.61). Also, $\mathrm{pH}$ had a high positive correlation between Spo (0.86) and BS (0.90). Biological and physicochemical indicators (SOC, AWHC, Silt, Gco, Spo, CEC, EC, $\mathrm{BS}$ and $\mathrm{pH}$ ) showed positive correlation coefficients between 0.60 and 0.91 , indicating that physicochemical processes tend to function simultaneously. However, these indicators may function differently, as expressed in the correlation table (Table 12). The trends are quite broad and high, with correlation coefficients between 0.14 and 0.91 .

\subsection{Sustainability Index Approach (SI)}

Soil physical, chemical and biological properties used for sustainability indexing are given in Table 9 and Table 10. The assessment was carried out for the 0 - to $20 \mathrm{~cm}$ soil depth. Among land use types, SOC, AWHC, Spo, CEC, EC and MBC had the highest values under forest land use. Table 13 shows sustainability indices calculated from soil indicators for the five (5) identified land use types. All the physico-chemical indices under forest had values above the sustainability rating threshold (refer to Table 3). For savannah woodland, indices recorded were below the sustainability line except for BD and MBC. For cropland (maize fields), only $\mathrm{BD}$ and $\mathrm{AWHC}$ were above the sustainability threshold (SI $>1$ ). For sustainability rating, Spo, BS and $\mathrm{pH}$ values were very high under all land use types. From Table 13, Forest and Grassland were sustainable (S) because these 
Table 12. Pearson product correlations between soil properties of the study site.

\begin{tabular}{|c|c|c|c|c|c|c|c|c|c|c|c|c|c|c|}
\hline Soil attributes & Clay & SOC & Sand & Silt & Spo & AWHC & $\mathrm{BD}$ & BS & $\mathrm{MBC}$ & CEC & $\mathrm{EC}$ & Gco & $\mathrm{pH}$ & SHC \\
\hline Clay & - & & & & & & & & & & & & & \\
\hline SOC & 0.55 & - & & & & & & & & & & & & \\
\hline Sand & -0.78 & -0.70 & - & & & & & & & & & & & \\
\hline Silt & 0.34 & 0.60 & -0.86 & - & & & & & & & & & & \\
\hline Spo & 0.18 & 0.46 & -0.30 & 0.30 & - & & & & & & & & & \\
\hline AWHC & 0.91 & 0.67 & -0.92 & 0.62 & 0.29 & - & & & & & & & & \\
\hline $\mathrm{BD}$ & -0.17 & -0.44 & 0.39 & -0.44 & -0.48 & -0.31 & - & & & & & & & \\
\hline BS & 0.29 & 0.37 & -0.45 & 0.44 & 0.80 & 0.38 & -0.36 & - & & & & & & \\
\hline $\mathrm{MBC}$ & 0.40 & 0.60 & -0.56 & 0.51 & 0.22 & 0.38 & -0.30 & 0.18 & - & & & & & \\
\hline CEC & 0.55 & 0.87 & -0.68 & 0.55 & 0.58 & 0.65 & -0.54 & 0.58 & 0.57 & - & & & & \\
\hline $\mathrm{EC}$ & 0.56 & 0.64 & -0.56 & 0.37 & 0.44 & 0.56 & -0.66 & 0.41 & 0.72 & 0.78 & - & & & \\
\hline Gco & 0.20 & 0.59 & -0.34 & 0.34 & 0.64 & 0.32 & -0.37 & 0.49 & 0.16 & 0.61 & 0.30 & - & & \\
\hline $\mathrm{pH}$ & 0.16 & 0.31 & -0.35 & 0.39 & 0.86 & 0.31 & -0.43 & 0.90 & 0.14 & 0.53 & 0.41 & 0.43 & - & \\
\hline SHC & -0.01 & 0.15 & -0.18 & 0.27 & 0.33 & 0.09 & -0.52 & 0.29 & 0.17 & 0.28 & 0.55 & -0.08 & 0.40 & - \\
\hline
\end{tabular}

Boldface factor loadings considered highly weighted were retained in the MDS [66]. Abbreviation: SOC, soil organic carbon (\%); $\mathrm{BD}$, bulk density $\left(\mathrm{g} / \mathrm{cm}^{3}\right)$; $\mathrm{BS}$, base saturation $(\%)$; $\mathrm{MBC}$, microbial biomass carbon $(\mathrm{mg} / \mathrm{kg})$; CEC, cation exchange capacity $\left(\mathrm{cmol}_{(+)} / \mathrm{kg}\right) ; \mathrm{pH}$, soil pH (1:2.5); Spo, soil porosity (\%); Gco, gravel content (\%); EC, electrical conductivity (dS/m); SHC, saturated hydraulic conductivity (cm/hr); AWHC, available water holding capacity (\%), Sand (\%); Silt (\%); Clay (\%).

Table 13. Sustainability indices (sustainability index approach) for the five land-use systems.

\begin{tabular}{|c|c|c|c|c|c|c|c|c|c|c|c|c|c|}
\hline \multirow{2}{*}{ Land use } & \multicolumn{11}{|c|}{ Indices } & \multirow[t]{2}{*}{ Mean } & \multirow{2}{*}{$\begin{array}{c}\text { SR (as } \\
\text { explained } \\
\text { in Table 3) }\end{array}$} \\
\hline & Spo & BD & AWHC & Gco & SHC & SOC & BS & CEC & $\mathrm{pH}$ & EC & $\mathrm{MBC}$ & & \\
\hline Forest & 1.25 & 0.90 & 1.38 & 2.56 & 1.03 & 2.04 & 1.08 & 2.17 & 1.15 & 1.67 & 2.05 & 1.57 & 1.57 \\
\hline $\begin{array}{l}\text { Savannah } \\
\text { Woodland }\end{array}$ & 0.81 & 1.04 & 0.86 & 0.00 & 0.98 & 0.79 & 0.91 & 0.64 & 0.84 & 0.84 & 1.77 & 0.86 & NS \\
\hline Grassland & 1.16 & 0.98 & 0.82 & 2.44 & 0.92 & 0.82 & 1.05 & 0.89 & 1.10 & 0.69 & 0.32 & 1.02 & 1.02 \\
\hline Fallow & 1.05 & 1.01 & 0.91 & 0.00 & 1.15 & 0.65 & 1.02 & 0.67 & 1.06 & 0.98 & 0.79 & 0.85 & NS \\
\hline Cropland & 0.73 & 1.07 & 1.02 & 0.00 & 0.92 & 0.70 & 0.95 & 0.64 & 0.86 & 0.82 & 0.07 & 0.71 & NS \\
\hline
\end{tabular}

Abbreviation: SOC, soil organic carbon (\%); BD, bulk density $\left(\mathrm{g} / \mathrm{cm}^{3}\right)$; BS, base saturation (\%); MBC, microbial biomass carbon $(\mathrm{mg} / \mathrm{kg}) ; \mathrm{CEC}$, cation exchange capacity $\left(\mathrm{cmol}_{(+)} / \mathrm{kg}\right) ; \mathrm{pH}$, soil $\mathrm{pH}(1: 2.5)$; Spo, soil porosity (\%); Gco, gravel content (\%); EC, electrical conductivity (dS/m); SHC, saturated hydraulic conductivity $(\mathrm{cm} / \mathrm{hr})$; AWHC, available water holding capacity (\%); SR (Sustainability Rating).

land use systems had a sustainability rating above the threshold. However, Savannah woodland, Fallow and Cropland were not sustainable (NS) because these land use types had low sustainability index ratings $(\mathrm{SI}<1)$. All arithmetic means 
computed for soil sustainability indicators are illustrated in Table 13.

\subsection{Cumulative Rating Approach (CR)}

Cumulative rating (CR) of soil properties for the five land use systems were computed using the total dataset (TDS) and the minimum dataset (MDS) concept. The relative weighting factor (RWF) of sustainability indicators for the five land use types and soil properties were computed for the study area. Spo, BD, EC and $\mathrm{MBC}$ had a high relative weighting factor (CR-TDS) of 1.00 for all land use systems. Cumulative rating using total dataset (CR-TDS) rating index of 19 was recorded for the forest (Table 14). This means the system is highly sustainable (HS). Savannah woodland and Grassland were sustainable and had a cumulative rating index of 24. Cropland and Fallow land-use systems had sustainability indices of 25 and 28, respectively. Both systems obtained a relative weighting factor (RWF) of 3.00, indicating that cropland and fallow are sustainable with high input (SWHI). For the 0 - to $20 \mathrm{~cm}$ soil depth, the CR-MDS for all land uses was sustainable with a sustainability index of 24 and a relative weighting factor of 2 , respectively (Table 14 and Table 15).

Using the cumulative rating-minimum dataset approach (CR-MDS), the forest had a high critical rating for all land uses. For CR-MDS, forest, savannah woodland and Grassland had high sustainability (HS) index of 10, 11 and 13 with an RWF of 1.00. This means that these three land use systems are highly sustainable (HS). On the other hand, cropland and fallow land use type had a CR-MDS of 25 and 26. This implies that these two land use systems are sustainable with high input (SWHI). However, the sustainability index (CR-MDS) for the 0 to $20 \mathrm{~cm}$ soil depth was 23.00 . This infers that the entire soil resources of the district are sustainable using the CR-MDS concept. From Figure 2, soil

Table 14. Soil physicochemical properties and their relative weighting factors in parentheses [Cumulative Rating Approach (MDS)].

\begin{tabular}{|c|c|c|c|c|c|c|c|c|c|c|}
\hline Land use & Spo & Text. & AWHC & Gco & BS & EC & $\mathrm{MBC}$ & CR & Mean & $\begin{array}{c}\text { SR (see Table } 5 \\
\text { and Table 6) }\end{array}$ \\
\hline Forest & $\begin{array}{c}61.40 \\
(1)\end{array}$ & $\begin{array}{l}\mathrm{L} \\
(1)\end{array}$ & $\begin{array}{c}29.45 \\
(2)\end{array}$ & $\begin{array}{c}39.63 \\
(3)\end{array}$ & $\begin{array}{c}99.00 \\
(1)\end{array}$ & $\begin{array}{c}187.00 \\
(1)\end{array}$ & $\begin{array}{c}158.00 \\
(1)\end{array}$ & 10 & 1.17 & HS \\
\hline $\begin{array}{l}\text { Savannah } \\
\text { Woodland }\end{array}$ & $\begin{array}{c}39.77 \\
(1)\end{array}$ & $\begin{array}{l}\text { SL } \\
(3)\end{array}$ & $\begin{array}{c}18.13 \\
(3)\end{array}$ & $\begin{array}{c}0.01 \\
(1)\end{array}$ & $\begin{array}{c}82.89 \\
(1)\end{array}$ & $\begin{array}{l}95.00 \\
(1)\end{array}$ & $\begin{array}{c}136.00 \\
(1)\end{array}$ & 11 & 1.67 & HS \\
\hline Grassland & $\begin{array}{c}57.05 \\
(1)\end{array}$ & $\begin{array}{l}\text { SL } \\
\text { (3) }\end{array}$ & $\begin{array}{c}17.43 \\
(3)\end{array}$ & $\begin{array}{c}37.77 \\
(3)\end{array}$ & $\begin{array}{c}95.64 \\
(1)\end{array}$ & $\begin{array}{c}77.50 \\
(1)\end{array}$ & $\begin{array}{c}25.04 \\
(1)\end{array}$ & 13 & 1.67 & HS \\
\hline Fallow & $\begin{array}{c}51.74 \\
(1)\end{array}$ & $\begin{array}{l}\text { SL } \\
(3)\end{array}$ & $\begin{array}{c}19.48 \\
(3)\end{array}$ & $\begin{array}{c}0.01 \\
(1)\end{array}$ & $\begin{array}{c}93.53 \\
(1)\end{array}$ & $\begin{array}{l}110 \\
(1)\end{array}$ & $\begin{array}{c}60.73 \\
(1)\end{array}$ & 25 & 1.67 & SWHI \\
\hline Cropland & $\begin{array}{c}36.00 \\
(1)\end{array}$ & $\begin{array}{l}\text { SL } \\
\text { (3) }\end{array}$ & $\begin{array}{c}21.83 \\
(2)\end{array}$ & $\begin{array}{c}0.01 \\
(1)\end{array}$ & $\begin{array}{c}86.49 \\
(1)\end{array}$ & $\begin{array}{c}92.50 \\
(2)\end{array}$ & $\begin{array}{c}5.33 \\
(4)\end{array}$ & 26 & 2.00 & SWHI \\
\hline
\end{tabular}

Abbreviation: SOC, soil organic carbon (\%); BD, bulk density $\left(\mathrm{g} / \mathrm{cm}^{3}\right) ; \mathrm{MBC}$, microbial biomass carbon (mg/kg); Spo, soil porosity (\%); Gco, gravel content (\%); EC, electrical conductivity (dS/m); AWHC, available water holding capacity (\%); CR, cumulative rating; SR, sustainability rating. 
Table 15. Soil physicochemical properties and their relative weighting factors in parentheses [Cumulative Rating Approach (TDS)].

\begin{tabular}{|c|c|c|c|c|c|c|c|c|c|c|c|c|c|c|}
\hline $\begin{array}{l}\text { Land } \\
\text { Use }\end{array}$ & Spo & $\mathrm{BD}$ & Texture & AWHC & Gco & SHC & SOC & BS & CEC & $\mathrm{pH}$ & EC & $\mathrm{MBC}$ & CR & $\begin{array}{c}\text { SR (as } \\
\text { explained in } \\
\text { Table } 5 \text { and } \\
\text { Table 6) }\end{array}$ \\
\hline Forest & $61.40(1)$ & $\begin{array}{l}1.02 \\
(1)\end{array}$ & $\begin{array}{l}\mathrm{L} \\
(1)\end{array}$ & $\begin{array}{c}29.45 \\
(2)\end{array}$ & $\begin{array}{c}39.63 \\
(3)\end{array}$ & $\begin{array}{l}0.18 \\
(3)\end{array}$ & $\begin{array}{l}2.18 \\
(3)\end{array}$ & $\begin{array}{c}99.00 \\
(1)\end{array}$ & $\begin{array}{c}14.10 \\
(1)\end{array}$ & $\begin{array}{c}6.55 \\
(1)\end{array}$ & $\begin{array}{c}187.50 \\
(1)\end{array}$ & $\begin{array}{c}158.00 \\
(1)\end{array}$ & 19 & HS \\
\hline $\begin{array}{l}\text { Savannah } \\
\text { Woodland }\end{array}$ & 39.77 (1) & $\begin{array}{l}1.18 \\
(1)\end{array}$ & $\begin{array}{l}\text { SL } \\
(3)\end{array}$ & $\begin{array}{c}18.13 \\
(3)\end{array}$ & $\begin{array}{c}0.01 \\
(1)\end{array}$ & $\begin{array}{l}0.17 \\
(3)\end{array}$ & $\begin{array}{c}0.84 \\
(4)\end{array}$ & $\begin{array}{c}82.89 \\
(1)\end{array}$ & $\begin{array}{l}4.15 \\
(4)\end{array}$ & $\begin{array}{l}4.80 \\
(1)\end{array}$ & $\begin{array}{c}95.00 \\
(1)\end{array}$ & $\begin{array}{c}136.51 \\
(1)\end{array}$ & 24 & $S$ \\
\hline Grassland & $57.05(1)$ & $\begin{array}{l}1.11 \\
(1)\end{array}$ & $\begin{array}{l}\text { SL } \\
(3)\end{array}$ & $\begin{array}{c}17.43 \\
(3)\end{array}$ & $\begin{array}{c}37.77 \\
(3)\end{array}$ & $\begin{array}{l}0.16 \\
(3)\end{array}$ & $\begin{array}{c}0.88 \\
(3)\end{array}$ & $\begin{array}{c}95.64 \\
(1)\end{array}$ & $\begin{array}{l}5.76 \\
(2)\end{array}$ & $\begin{array}{l}6.25 \\
(2)\end{array}$ & $\begin{array}{c}77.50 \\
(1)\end{array}$ & $\begin{array}{c}25.04 \\
(1)\end{array}$ & 24 & $S$ \\
\hline Fallow & $51.74(1)$ & $\begin{array}{l}1.15 \\
(1)\end{array}$ & $\begin{array}{l}\text { SL } \\
(3)\end{array}$ & $\begin{array}{c}19.48 \\
(3)\end{array}$ & $\begin{array}{c}0.01 \\
(1)\end{array}$ & $\begin{array}{c}0.20 \\
(2)\end{array}$ & $\begin{array}{c}0.70 \\
(4)\end{array}$ & $\begin{array}{c}93.53 \\
(1)\end{array}$ & $\begin{array}{l}4.35 \\
(4)\end{array}$ & $\begin{array}{l}6.05 \\
(3)\end{array}$ & $\begin{array}{c}110.00 \\
(1)\end{array}$ & $\begin{array}{c}60.73 \\
(1)\end{array}$ & 25 & SWHI \\
\hline Cropland & $36.00(1)$ & $\begin{array}{l}1.21 \\
9(1)\end{array}$ & $\begin{array}{l}\text { SL } \\
(3)\end{array}$ & $\begin{array}{c}21.83 \\
(2)\end{array}$ & $\begin{array}{c}0.01 \\
(1)\end{array}$ & $\begin{array}{l}0.16 \\
(3)\end{array}$ & $\begin{array}{c}0.75 \\
(4)\end{array}$ & $\begin{array}{c}86.49 \\
(1)\end{array}$ & $\begin{array}{l}4.17 \\
(4)\end{array}$ & $\begin{array}{l}4.88 \\
(3)\end{array}$ & $\begin{array}{c}92.50 \\
(1)\end{array}$ & $\begin{array}{l}5.33 \\
(4)\end{array}$ & 28 & SWHI \\
\hline
\end{tabular}

Abbreviation: SOC, soil organic carbon (\%); BD, bulk density $\left(\mathrm{g} / \mathrm{cm}^{3}\right)$; BS, base saturation (\%); $\mathrm{MBC}$, microbial biomass carbon $(\mathrm{mg} / \mathrm{kg})$; CEC, cation exchange capacity $\left(\mathrm{cmol}_{(+)} / \mathrm{kg}\right) ; \mathrm{pH}$, soil $\mathrm{pH}(1: 2.5)$; Spo, soil porosity (\%); Gco, gravel content (\%); EC, electrical conductivity $(\mathrm{dS} / \mathrm{m})$; SHC, saturated hydraulic conductivity $(\mathrm{cm} / \mathrm{hr}) ;$ AWHC, available water holding capacity $(\%)$, CR, cumulative rating.

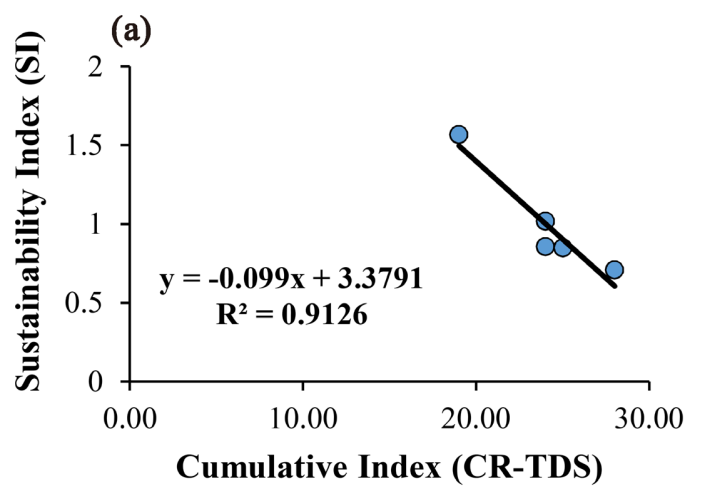

(c)

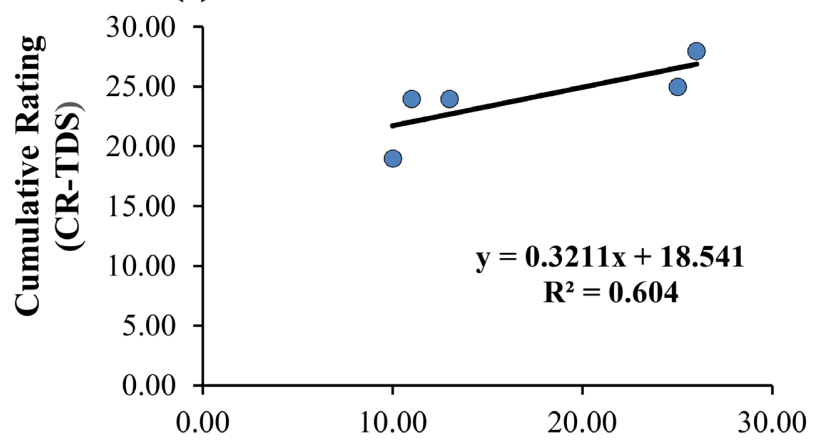

(b)

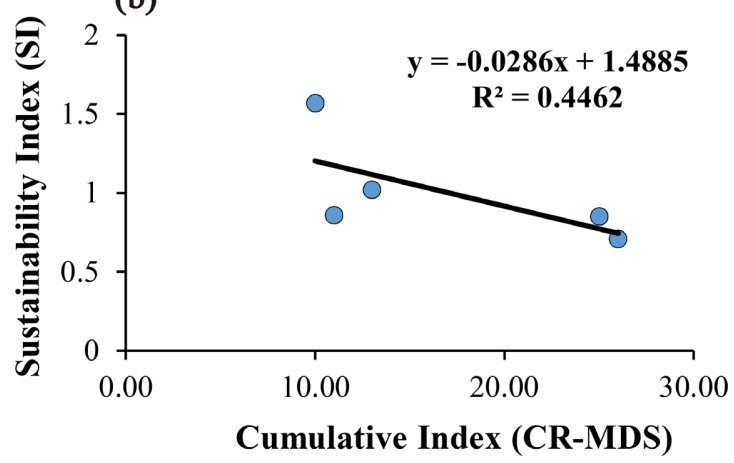

Cumulative Rating (CR-MDS)

Figure 2. Relationship between (a) Sustainability index (SI) and Cumulative rating (CR-TDS), (b) Sustainability index (SI) and Cumulative index (CR-MDS), and (c) Cumulative rating (CR-TDS) and Cumulative rating (CR-MDS) of land use types. 
sustainability index (SI) and cumulative rating (CR-MDS) were strongly correlated $(r=0.60, p<0.05)$. This indicates that as sustainability index increases, soil quality or health improves. Also, SI and CR-TDS had a high correlation ( $\mathrm{r}=$ $0.91, \mathrm{p}<0.05)$, and this means that as cumulative rating increases, soil quality deteriorates.

\section{Discussion}

\subsection{Expert Opinion (EO)}

The selected soil quality indicators were based on available data and literature on soil resources of the Nkoranza District. Also, environmental factors (temperature and rainfall) with associated pedogenic processes, according to Mueller et al. (2010) [67], modified soil properties over the years. Expert opinion assisted in selecting soil variables as indicators for assessing soil quality and/or health. Evaluation of soil structure through visual examination procedures assisted in acquiring information on soil features and functions related to soil morphological characteristics [68] identified in the study area. Visual Soil Assessment (VSA) and/or Visual Evaluation of Soil Structure (VESS) methods gave a reliable rating based on visual diagnostic criteria [69]. Moncada et al. (2014) [69] and Vasu et al. (2016) [70] stressed that selected indicators should genuinely reflect the complexity and functions of soil resources for food-crop production systems. For example, clay, a soil variable, influences soil management and productivity. A soil with an adequate amount of clay $(15 \%-20 \%)$ and silt was selected as the most productive soil, while soils with clay content $>35 \%$ did pose problems related to management (drainage and aeration). Soil hydraulic conductivity and available water holding capacity were important indicators because they control soil moisture distribution and availability of water to crops. Soil organic carbon was retained because it serves as an essential soil quality indicator. Also, SOC plays a major role in smallholder rainfed agricultural systems of the tropics [71]. Again, it influences soil nutrient supply, moisture retention, and stability of soil physical properties such as soil texture [72]. Cation exchange capacity was considered an indicator because it influences nutrient supply capacity, and this depends on the quantity and quality of clay, organic matter and soil $\mathrm{pH}$ [70] [73] [74] [75] [76] [77]. The selected soil parameters were given weightage. This assisted in the calculation of weightage for SI, CR-TDS and CR-MDS. The weightage factors/scoring method developed by Lal (1994) [60], Singh and Khera (2009) [23] were used to assign weightage (Table 5 and Table 6).

\subsection{Selection of a Minimum Dataset (MDS) for Soil Sustainability Assessment}

The PCA, a multivariate statistical approach, was used to select soil quality indicators from a large dataset. However, under all five principal components (PCs), only variables with the highest factor loading were retained as indicators of soil sustainability assessment. If more than one variable is retained under a PC, mul- 
tivariate analysis and/or correlation is performed to determine which variables could be considered redundant and subsequently eliminated from the data set. However, if factors are highly loaded yet not correlated, each was considered important and included in the MDS. Also, MBC, EC, Spo, BS, Gco, Clay, Sand, Silt, and AWHC had high factor loadings. These variables significantly correlated statistically and were retained for the MDS. Overall, these variables were retained as MDS and used for soil sustainability assessment in the Nkoranza district. This is consistent with several studies that used soil properties such as $\mathrm{pH}$, SOC, BS, MBC, Spo and soil particle-size distribution (sand, silt and clay content) to assess soil sustainability [20] [78] [79]. According to Yao et al. (2013) [80], most of these indicators highly correlate with crop (maize) yield and positively influence soil quality. Ghaemi et al. (2014) [20] stressed that these indicators could be used as decision support tools for soil management practices. Furthermore, the selected indicators can serve as an indirect measure of soil function. It can be used to assess soil quality and its change with time for a short and/or long-term period [81]. This can adequately account for soil property dynamics in the 0 to $20 \mathrm{~cm}$ soil depth for sustainable maize-crop production in smallholder farming systems in the Nkoranza (North and South) District. Most studies [70] [78] [82] [83] indicated that the upper layer $(0-20 \mathrm{~cm})$ accounts for anthropogenic activities and other natural factors that go on in the soil medium.

\subsection{Sustainability Assessment (Sustainability Index and Cumulative Rating Approach)}

There are several ways to determine the sustainability of an agricultural production system. For example, Ghaemi et al. (2014) [20] indicated that PCA increased the efficiency of the cumulative rating approach (CRA) to sustainability assessment in an agricultural production system. Also, Gomez et al. (1996) [21] introduced the sustainability index (SI) approach to assess the sustainability of soils in different agricultural management systems. The cumulative rating (CR) approach by Shukla et al. (2004) [22] uses critical levels, which are classified into no limitation to an extreme limitation on a scale of 1 - 5 using a relative weighting factor (RWF) based on selected physical, chemical and biological properties of soil. Some authors use both methods, thus sustainability index and cumulative rating approach for sustainability assessment [23]. However, an agricultural production system [24] can be assessed by evaluating temporal changes using the sustainability index approach [25]. The above discussion showed a strong correlation $\left(\mathrm{R}^{2}=0.91, \mathrm{p}=0.05\right)$ between sustainability $(\mathrm{SI})$ and the cumulative rating $(\mathrm{CR})$ approach (Figure 2).

However, CR-TDS and CR-MDS indicated a moderate positive correlation ( $\mathrm{R}^{2}$ $=0.60, \mathrm{p}=0.05)$. Therefore, a low cumulative rating means the system is functioning at a high level of sustainability. Also, cumulative ratings using total data set (CR-TDS) for soil sustainability assessment were observed following the order: Forest $<$ Grassland $=$ Savannah woodland $<$ Fallow $<$ Cropland $($ Table 14) . 
For CR-MDS, it was in the order: Forest $<$ Savannah woodland $<$ Grassland $<$ Fallow $<$ Cropland. Sustainability indices for the five land-use systems followed the order: Forest $<$ Grassland $<$ Savannah woodland $<$ Fallow $<$ cropland (Table 15). However, sustainability index for the $0-20 \mathrm{~cm}$ soil depth was low $(\mathrm{SI}<1)$, which implies that the entire soil resources of the Nkoranza (north and south) district is functioning at a moderate capacity, thus sustainable with high input (SWHI) for cropland and fallow land-use systems.

A strong relationship $\left(\mathrm{R}^{2}=0.91, \mathrm{p}<0.05\right)$ observed between SI and CR-TDS proved that these two methods were efficient in the determination of soil quality (Figure 2(a)). Similarly, SI versus CR-TDS and SI versus CR-MDS methods were negatively correlated as expected (see Figure 2). Ghaemi et al. (2014) [20] and Emami et al. (2012) [84] reported a high negative correlation between SI and CR-TDS. According to Singh and Khera (2009) [23], a high SI indicates an improvement in soil quality, and a higher CR indicates low soil quality. In our study, the SI approach was preferred to CR-TDS since fewer indicators were used. This affirmed that PCA is an effective data reduction tool [22] [85] and it increased the efficiency of CR in soil sustainability assessment [20] [86]. Furthermore, the differences between CR-TDS and CR-MDS and the high correlation between $\mathrm{CR}$ and soil indicators used as MDS proved that SOC, MBC, BS, EC, Spo, and sand were the most important soil variables for soil sustainability assessment in the study area.

\subsection{Soil Sustainability Index as an Indicator of Agricultural Sustainability}

Soil sustainability assessment is an intermediary for conservation agricultural management practices [87] and sustainable agriculture. According to Acton and Gregorich (1995) [88], these practices play a key role in achieving sustainable development goals related to agriculture and the environment. However, assessing soil quality and/or health and the direction of change with time is the primary indicator of sustainable land management [89] [90]. The quality of the soil determines its agricultural sustainability [88], environmental quality [91], as well as plant, animal, and human health. For example, the SOC level in cropland was low, and this depends on the rate of nutrient input compared to soil nutrient loss. Agricultural intensification without manuring or use of mineral fertiliser decreases SOC. This destabilises the soil and exposes it to degradation agents, rendering Fallow and Cropland sustainable with high input (SWHI).

Several research findings stress the importance of SOC as an indicator of soil quality [9] [13] [20] [21] [22] [23] [24] [89]. The sustainability index rating for soil quality indicators indicated that Forest and Grassland functioned above the threshold compared to Savannah woodland, Fallow and Cropland, with a low sustainability index rating of less than $1(\mathrm{SI}<1)$. Thus, soil scientists contribute significantly to sustainable land management. This can be achieved through the translation of scientific knowledge and information on soil function into prac- 
tical tools. These approaches can assist land managers during sustainability assessment of their management practices [92] [93] [94]. The interconnection (high correlation values) between physico-chemical indicators can be explained through chelation with the possible effect of outliers [95]. This process plays an essential role in soil quality and/or health restoration. Magdoff and van Es (2009) [96] found that this process enhances the availability of soil nutrients to plants and its uptake through plant roots hence the acceleration of nutrient transfer. This could result in accelerated growth hence, an increase in yield [97].

From the above, most soil attributes were positively and negatively correlated, showing similar spatial distribution patterns. The correlation among these soil properties indicated that PC analysis summarised major variability sources in the data set. Soil quality assessment is important because it assists in identifying challenges associated with production functions, estimation of a food production system, and sustainability assessment of agricultural management systems. These can assist policymakers (government agencies) in formulating and evaluating agricultural production systems [98]. Using simple indicators that have meaning to farmers and other land managers will likely be the most fruitful means to link science and policy with practice in assessing agricultural land use management systems sustainably [99] on smallholder farms. There are several criteria to consider when selecting indicators. In general, appropriate indicators should be: easy to assess, measure changes in soil function, for example, at the plot (smallholder farm) and landscape level, to make management decisions accessible to farmers.

\subsection{Sensitivity Analysis}

Variability in soil attributes depended on the soil sampling time, prevailing land use, topography, slope and climate. Also, selected indicators (SOC, MBC, CEC, EC, Silt and Clay) sensitive to variation in this agro-ecological zone were used to represent the physical, chemical and biological properties of soil, assessed by qualitative (using the cumulative variance rating) and/or quantitative approach [100]. Silt and clay relate to soil texture (soil aggregate and structure), while EC, SOC, MBC and CEC are associated with soil fertility. Soil texture (silt and clay) exhibited a moderate sensitivity due to the intrinsic (inherent) soil property associated with the parent material rather than prevailing environmental conditions. This indicates the long-term effect of land-use change by smallholders as indicated by a moderate sensitivity coefficient of variation (CV) (Table 8). Using the PCA and variance analysis results, SOC, MBC and CEC relating to the fertility component were identified as the most influential (sensitive) indicators to soil sustainability assessment. The selected indicators can be used to assess and monitor soil sustainability due to land-use change due to soil mismanagement by smallholders in the humid Savanna zone of Ghana. In a similar research using soil quality indicators, Xu et al. (2006) [64] identified SOM, Av. P, urease and hydraulic conductivity as the most sensitive indicators to land-use change 
using PCA and variance analysis. In most scientific literature, Doran and Parkin (1994) [101] indicated that any basic soil quality indicator should reflect a criterion relevant to the existing soil database.

\section{Conclusion}

In conclusion, $\mathrm{SOC}, \mathrm{MBC}, \mathrm{BS}, \mathrm{EC}$, Spo and sand were the most important variables selected as MDS using PC analysis. Also, CR-TDS and CR-MDS proved useful compared to SI versus CR-TDS and SI versus CR-MDS. Forest and Grassland had high sustainability (HS) index while Savannah woodland, Fallow and Cropland were not sustainable (NS). For CR-TDS, Forest had a high sustainability index, Savannah woodland and Grassland were sustainable (S) compared to Fallow and Cropland, which were sustainable with high input (SWHI). Also, CR-MDS rating for Forest, Savannah woodland, and Grassland had high sustainability ( $\mathrm{SH}$ ) indices compared to Fallow and Cropland, rated as sustainable with high input (SWHI). Data analysis indicated that indicators could be used to assess the sensitivity of sustainability processes and changes relating to soil management in farmers' fields. The use of indicators for SI assessment and the adoption of new strategies for sustainable land management are linked to the development of management systems that maintain acceptable productivity levels on the soil landscape. Therefore, the results of this study can be used in the formulation of strategies that conserve soil resources in the Savannah Transition agro-eco zone of Ghana.

\section{Acknowledgements}

The authors wish to thank Mr. Michael Asuboah (CSIR-Soil Research Institute, Ghana) for his assistance during soil sampling in the Nkoranza (North and South) District.

\section{Conflicts of Interest}

The authors declare no conflicts of interest regarding the publication of this paper.

\section{References}

[1] Food and Agriculture Organization of the United Nations (2015) FAOSTAT Database. FAOSTAT Database Collections, Rome.

[2] Godfray, H.C.J., Beddington, J.R., Crute, I.R., Haddad, L., Lawrence, D., Muir, J.F. and Toulmin, C. (2010) Food Security: The Challenge of Feeding 9 Billion People. Science, 327, 812-818. https://doi.org/10.1126/science.1185383

[3] Mungai, L.M., Snapp, S., Messina, J.P., Chikowo, R., Smith, A., Anders, E. and Li, G. (2016) Smallholder Farms and the Potential for Sustainable Intensification. Frontiers in Plant Science, 7, 1720. https://doi.org/10.3389/fpls.2016.01720

[4] Dirzo, R. and Raven, P.H. (2003) Global State of Biodiversity and Loss. Annual Review of Environment and Resources, 28, 137-167. https://doi.org/10.1146/annurev.energy.28.050302.105532 
[5] Legg, W. (2006) Policy Efforts to Achieve Sustainable Agriculture: An OECD Perspective. In: Brouwer, F. and McCarl, B.A., Eds., Agriculture and Climate beyond 2015, Environment \& Policy, Vol. 46, Springer, Dordrecht, 265-277. https://doi.org/10.1007/1-4020-4368-6 15

[6] Gibbon, D. (2012) Save and Grow: A Policymaker's Guide to the Sustainable Intensification of Smallholder Crop Production. Rome, Italy: Food and Agriculture Organization of the United Nations (2011), pp. 112, US\$45.00. ISBN 978-92-5-106871-7. Experimental Agriculture, 48, 154. https://doi.org/10.1017/S0014479711001049

[7] Frater, P. and Franks, J. (2013) Measuring Agricultural Sustainability at the Farm-Level: A Pragmatic Approach. International Journal of Agricultural Management, 2, 207-225. https://doi.org/10.5836/ijam/2013-04-04

[8] AGRA (2018) Africa Agriculture Status Report: Catalyzing Government Capacity to Drive Agricultural Transformation (Issue 6). Nairobi, Kenya.

[9] Andrews, S.S. and Carroll, C.R. (2001) Designing a Soil Quality Assessment Tool for Sustainable Agroecosystem Management. Ecological Applications, 11, 1573-1585. https://doi.org/10.1890/1051-0761(2001)011[1573:DASQAT]2.0.CO;2

[10] Edwards, C.A., Grove, T.L., Harwood, R.R. and Colfer, C.P. (1993) The Role of Agroecology and Integrated Farming Systems in Agricultural Sustainability. Agriculture, Ecosystems and Environment, 46, 99-121. https://doi.org/10.1016/0167-8809(93)90017-I

[11] Pretty, J.N. (1995) Regenerating Agriculture: Policies and Practice for Sustainability and Self-Reliance. Earthscan Publications, London.

[12] Pretty, J.N. (1995) Participatory Learning for Sustainable Agriculture. World Development, 23, 1247-1263. https://doi.org/10.1016/0305-750X(95)00046-F

[13] Goswami, R., Saha, S. and Dasgupta, P. (2017) Sustainability Assessment of Smallholder Farms in Developing Countries. Agroecology and Sustainable Food Systems, 41, 546-569. https://doi.org/10.1080/21683565.2017.1290730

[14] Bechini, L. and Castoldi, N. (2009) On-Farm Monitoring of Economic and Environmental Performances of Cropping Systems: Results of a 2-Year Study at the Field Scale in Northern Italy. Ecological Indicators, 9, 1096-1113.

https://doi.org/10.1016/j.ecolind.2008.12.008

[15] Abraham, M. and Pingali, P. (2020) Transforming Smallholder Agriculture to Achieve the SDGs. In: Gomez y Paloma, S., Riesgo, L. and Louhichi, K., Eds., The Role of Smallholder Farms in Food and Nutrition Security, Springer, Cham, 173-209. https://doi.org/10.1007/978-3-030-42148-9 9

[16] Pretty, J. (2008) Agricultural Sustainability: Concepts, Principles and Evidence. Philosophical Transactions of the Royal Society B: Biological Sciences, 363, 447-465. https://doi.org/10.1098/rstb.2007.2163

[17] Carter, M.R. (2002) Soil Quality for Sustainable Land Management: Organic Matter and Aggregation Interactions That Maintain Soil Functions. Agronomy Journal, 94, 38-47. https://doi.org/10.2134/agronj2002.0038

[18] Warkentin, B.P. (1995) The Changing Concept of Soil Quality. Journal of Soil and Water Conservation, 50, 226-228.

[19] Miller, F.P. and Wali, M.K. (1995) Soils, Land Use and Sustainable Agriculture: A Review. Canadian Journal of Soil Science, 75, 413-422.

https://doi.org/10.4141/cjss95-061

[20] Ghaemi, M., Astaraei, A.R., Emami, H., Nassiri Mahalati, M. and Sanaeinejad, S.H. 
(2014) Determining Soil Indicators for Soil Sustainability Assessment Using Principal Component Analysis of Astan Quds-East of Mashhad-Iran. Journal of Soil Science and Plant Nutrition, 14, 1005-1020. https://doi.org/10.4067/S0718-95162014005000077

[21] Gomez, A.A., Kelly, D.E.S., Syers, J.K. and Coughlan, K.J. (1997) Measuring Sustainability of Agricultural Systems at the Farm Level. In: Doran, J.W. and Jones, A.J., Eds., Methods for Assessing Soil Quality, Vol. 49, The Soil Science Society of America, Inc., Madison, WI, 401-410. https://doi.org/10.2136/sssaspecpub49.c26

[22] Shukla, M.K., Lal, R. and Ebinger, M. (2004) Principal Component Analysis for Predicting Corn Biomass and Grain Yields. Soil Science, 169, 215-224. https://doi.org/10.1097/01.ss.0000122521.03492.eb

[23] Singh, M.J. and Khera, K.L. (2009) Physical Indicators of Soil Quality in Relation to Soil Erodibility under Different Land uses. Arid Land Research and Management, 23, 152-167. https://doi.org/10.1080/15324980902817147

[24] Dhaliwal, S.S., Sharma, B.D. and Bijay, S. (2009) Micronutrient Status of Different Land Use Systems in Relation to Soil Quality and Sustainability under Different Watersheds in Submontaneous Tract of Punjab. Annals of Arid Zone, 48, 103-112.

[25] Lal, R. (2004) Soil Carbon Sequestration Impacts on Global Climate Change and Food Security. Science, 304, 1623-1627. https://doi.org/10.1126/science.1097396

[26] Ghana Statistical Service (2014) 2010 Population and Housing Census. District Analytical Report-Nkoranza North District. Accra, Ghana.

[27] Ghana Statistical Service (2014) 2010 Population and Housing Census. District Analytical Report-Nkoranza South Municipality. Accra, Ghana.

[28] Ghana Statistical Service (2010) 2010 Population and Housing Census. Accra, Ghana.

[29] Peel, M.C., Finlayson, B.L. and McMahon, T.A. (2007) Updated World Map of the Köppen-Geiger Climate Classification. Hydrology and Earth System Sciences, 11, 1633-1644. https://doi.org/10.5194/hess-11-1633-2007

[30] Kasei, C.N. (1990) A Synopsis on the Climate of the North of Ghana. 2nd Workshop on Improving Farming Systems in the Savanna Zone of Ghana, 24 April 1990.

[31] Dickson, K.B. and Benneh, G. (1995) A New Geography of Ghana. 3rd Edition, Longman Group Limited, Essex, England.

[32] Christensen, E. and Awadzi, T.W. (2000) Water Balance in a Moist Semi-Deciduous Forest of Ghana. West African Journal of Applied Ecology, 1, 11-22. https://doi.org/10.4314/wajae.v1i1.40566

[33] Walker, H.O. (1962) Weather and Climate. In: Wills, J.B., Ed., Agriculture and Land use in Ghana, Ministry of Food and Agriculture, Oxford University Press, London, 3-50.

[34] Smith, G.K. (1962) Report on Soil and Agricultural Survey of Sene-Obosum River Basins, East Brong-Ahafo and Ashanti Regions, Ghana. US Agency for International Development.

[35] Bationo, B.A., Tabo, R., Waswa, B.S., Okeyo, J., Kihara, J., Fosu, M. and Kabore, S. (2008) Synthesis of Soil Water and Nutrient Management Research in the Volta Basin. Ecomedia Limited, Nairobi.

[36] Junner, N.R. and Hirst, T. (1946) The Geology and Hydrogeology of the Volta Basin. Gold Coast Geological Survey, Memoir, 8, 837-854.

[37] IUSS Working Group WRB (2015) International Soil Classification System for 
Naming Soils and Creating Legends for Soil Maps. World Reference Base for Soil Resources 2014, Update 2015, 106.

[38] Adu, S.V. and Mensah-Ansah, J.A. (1995) Soils of the Afram Basin, Ashanti and Eastern Regions, Ghana. Memoir No. 12, Soil Research Institute, Ghana.

[39] Asiamah, R.D. (2008) Soil Resources in Ghana. Synthesis of Soil, Water and Nutrient Management Research in the Volta Basin. Ecomedia Ltd., Nairobi, 25-41.

[40] Brand, B. and Brammer, H. (1956) Provisional Grassland Associations of Interior and Coastal Savannah Zones of Gold Coast. Gold Coast Department of Soil and Land-Use Survey. Technical Report No. 21, 17.

[41] Aynekulu, E., Carletto, C., Gourlay, S. and Shepherd, K. (2016) Soil Sampling in Household Surveys: Experience from Ethiopia. The World Bank, Washington, DC and World Agroforestry Centre, Nairobi, 26, 17-18.

[42] Gourlay, S., Aynekulu, E., Shepherd, K., Carletto, C., Gourlay, S., Aynekulu, E. and Carletto, C. (2017) Collecting the Dirt on Soils: Advancements in Plot-Level Soil Testing and Implications for Agricultural Statistics (No. 8057). The World Bank.

[43] Vâgen, T.G., Winowiecki, L.A., Walsh, M.G., Tamene, L. and Tondoh, J.E. (2010) Land Degradation Surveillance Framework (LSDF): Field Guide. International Center for Tropical Agriculture, World Agroforestry Centre, and the Earth Institute at Columbia University.

[44] Adjei-Gyapong, T. and Asiamah, R.D. (2002) The Interim Ghana Soil Classification System and Its Relation with the World Reference Base Soil Resources. Rapport sur les Ressources en Sols du Monde (FAO).

[45] Gardner, W.H. (1986) Water Content. In: Klute, A., Ed., Methods of Soil Analysis. Part 1 Physical and Mineralogical Methods, 5.1, American Society of Agronomy, Inc. Soil Science Society of America, Inc., Madison, WI, 493-544. https://doi.org/10.2136/sssabookser5.1.2ed.c21

[46] Blake, G.R. and Hartge, K.H. (1986) Bulk Density. In: Arnold Klute, Ed., Methods of Soil Analysis: Part 1 Physical and Mineralogical Methods, 5.1, The American Society of Agronomy, Inc., Soil Science Society of America, Inc., Madison, WI, 363-375. https://doi.org/10.2136/sssabookser5.1.2ed.c13

[47] Bouyoucos, G.J. (1962) Hydrometer Method Improved for Making Particle Size Analyses of Soils. Agronomy Journal, 54, 464-465.

https://doi.org/10.2134/agronj1962.00021962005400050028x

[48] Rowell, D.L. (2014) Soil Science: Methods and Applications. Routledge, London. https://doi.org/10.4324/9781315844855

[49] Jackson, M.L. (1973) Soil Chemical Analysis. Prentice Hall of India Pvt. Ltd., New Delhi, 498 p.

[50] Bremner, J. and Mulvaney, C. (1982) Nitrogen-Total. In: Page, A.L., Ed., Methods of Soil Analysis. Part 2: Chemical and Microbiological Properties, American Society of Agronomy, Madison, WI, 595-624.

https://doi.org/10.2134/agronmonogr9.2.2ed.c31

[51] Olsen, S.R. (1954) Estimation of Available Phosphorus in Soils by Extraction with Sodium Bicarbonate (No. 939). US Department of Agriculture.

[52] Sparks, D.L., Page, A.L., Helmke, P.A. and Loeppert, R.H., Eds. (2020) Methods of Soil Analysis, Part 3: Chemical Methods, Vol. 14. John Wiley \& Sons, Hoboken.

[53] Thomas, G.W. (1983) Exchangeable Cations. In: Page, A.L., Ed., Methods of Soil Analysis. Part 2 Chemical and Microbiological Properties, 9.2.2, American Society 
of Agronomy, Madison, WI, 159-165.

https://doi.org/10.2134/agronmonogr9.2.2ed.c9

[54] Sparling, G.P. and Ross, D.J. (1993) Biochemical Methods to Estimate Soil Microbial Biomass: Current Developments and Applications. In: Mulangoy, K. and Merckx, R., Eds., Soil Organic Matter Dynamics and Sustainability of Tropical Agriculture. Wiley, Chichester, 21-37.

[55] Dunteman, G.H. (1989) Principal Components Analysis (No. 69). Sage, Thousand Oaks, CA.

[56] Kaiser, H.F. (1960) The Application of Electronic Computers to Factor Analysis. Educational and Psychological Measurement, 20, 141-151. https://doi.org/10.1177/001316446002000116

[57] Wander, M.M. and Bollero, G.A. (1999) Soil Quality Assessment of Tillage Impacts in Illinois. Soil Science Society of America Journal, 63, 961-971. https://doi.org/10.2136/sssaj1999.634961x

[58] Andrews, S.S., Karlen, D.L. and Mitchell, J.P. (2002) A Comparison of Soil Quality Indexing Methods for Vegetable Production Systems in Northern California. Agriculture, Ecosystems \& Environment, 90, 25-45. https://doi.org/10.1016/S0167-8809(01)00174-8

[59] Andrews, S.S., Mitchell, J.P., Mancinelli, R., Karlen, D.L., Hartz, T.K., Horwath, W.R. and Munk, D.S. (2002) On-Farm Assessment of Soil Quality in California's Central Valley. Agronomy Journal, 94, 12-23. https://doi.org/10.2134/agronj2002.0012

[60] Lal, R. (1994) Sustainable Land use Systems and Soil Resilience. In: Greenland, D.J. and Szabolcs, I., Eds., Soil Resilience and Sustainable Land Use, CAB International Publishers, Wallingford, 41-67.

[61] Adeyolanu, O.D. and Ogunkunle, A.O. (2016) Comparison of Qualitative and Quantitative Approaches to Soil Quality Assessment for Agricultural Purposes in South-Western Nigeria. Cogent Food \& Agriculture, 2, Article ID: 1149914.

[62] Nielsen, D.R. and Bouma, J. (1985) Soil Spatial Variability: Proceedings of a Workshop of the ISSS and the SSSA, Las Vegas, USA/Pdc296. Center Agricultural Pub and Document, Pudoc, Wageningen, The Netherlands.

[63] Kassa, H., Dondeyne, S., Poesen, J., Frankl, A. and Nyssen, J. (2017) Impact of Deforestation on Soil Fertility, Soil Carbon and Nitrogen Stocks: The Case of the Gacheb Catchment in the White Nile Basin, Ethiopia. Agriculture, Ecosystems \& Environment, 247, 273-282. https://doi.org/10.1016/j.agee.2017.06.034

[64] Xu, M., Zhao, Y., Liu, G. and Wilson, G.V. (2006) Identification of Soil Quality Factors and Indicators for the Loess Plateau of China. Soil Science, 171, 400-413.

[65] Tan, Z., Tieszen, L.L., Tachie-Obeng, E., Liu, S. and Dieye, A.M. (2009) Historical and Simulated Ecosystem Carbon Dynamics in Ghana: Land Use, Management, and Climate. Biogeosciences, 6, 45-58. https://doi.org/10.5194/bg-6-45-2009

[66] Ray, S.K., Bhattacharyya, T., Reddy, K.R., et al. (2014) Soil and Land Quality Indicators of the Indo-Gangetic Plains of India. Current Science, 107, 1470-1486. http://www.jstor.org/stable/24107210

[67] Mueller, L., Schindler, U., Mirschel, W., et al. (2010) Assessing the Productivity Function of Soils. A Review. Agronomy for Sustainable Development, 30, 601-614. https://doi.org/10.1051/agro/2009057

[68] Mueller, L., Shepherd, G., Schindler, U., et al. (2013) Evaluation of Soil Structure in 
the Framework of an Overall Soil Quality Rating. Soil and Tillage Research, 127, 74-84. https://doi.org/10.1016/j.still.2012.03.002

[69] Moncada, M.P., Gabriels, D. and Cornelis, W.M. (2014) Data-Driven Analysis of Soil Quality Indicators Using Limited Data. Geoderma, 235, 271-278.

https://doi.org/10.1016/j.geoderma.2014.07.014

[70] Vasu, D., Singh, S.K., Ray, S.K., et al. (2016) Soil Quality Index (SQI) as a Tool to Evaluate Crop Productivity in Semi-Arid Deccan Plateau, India. Geoderma, 282, 70-79. https://doi.org/10.1016/j.geoderma.2016.07.010

[71] Lal, R. (2016) Why Carbon Sequestration in Agricultural Soils. In: Kimble, J.M., Lal, R. and Follett, R.F., Eds., Agricultural Practices and Policies for Carbon Sequestration in Soil, CRC Press, Boca Raton, 45-54. https://doi.org/10.1201/9781420032291-7

[72] Bhattacharyya, T., Pal, D.K. and Easter, M. (2007) Modelled Soil Organic Carbon Stocks and Changes in the Indo-Gangetic Plains, India from 1980 to 2030. Agriculture, Ecosystem, Environment, 122, 84-94. https://doi.org/10.1016/j.agee.2007.01.010

[73] Bationo, A., Kihara, J., Vanlauwe, B., Waswa, B. and Kimetu, J. (2007) Soil Organic Carbon Dynamics, Functions and Management in West African Agro-Ecosystems. Agricultural Systems, 94, 13-25. https://doi.org/10.1016/j.agsy.2005.08.011

[74] Hartemink, A.E. (2006) Soil Fertility Decline: Definitions and Assessment. In: Encyclopedia of Soil Science, Vol. 2, Taylor and Francis, New York, 1618-1621.

[75] Hartemink, A.E. (2006) Assessing Soil Fertility Decline in the Tropics Using Soil Chemical Data. Advances in Agronomy, 89, 179-225. https://doi.org/10.1016/S0065-2113(05)89004-2

[76] Bekunda, M., Sanginga, N. and Woomer, P.L. (2010) Restoring Soil Fertility in Sub-Sahara Africa. Advances in Agronomy, 108, 183-236.

https://doi.org/10.1016/S0065-2113(10)08004-1

[77] Brady, N.C. and Weil, R. (2008) Nature and Properties of Soils. 14th Edition, Pearson Education, Upper Saddle River, NJ.

[78] Takoutsing, B., Weber, J., Aynekulu, E., Martín, J.A.R., Shepherd, K., Sila, A. and Diby, L. (2016) Assessment of Soil Health Indicators for Sustainable Production of Maize in Smallholder Farming Systems in the Highlands of Cameroon. Geoderma, 276, 64-73. https://doi.org/10.1016/j.geoderma.2016.04.027

[79] Triantafyllidis, V., Kosma, A.K.C. and Patakas, A. (2018) An Assessment of the Soil Quality Index in a Mediterranean Agro Ecosystem. Emirates Journal of Food and Agriculture, 30, 1042-1050.

[80] Yao, R., Yang, J., Gao, P., Zhang, J. and Jin, W. (2013) Determining Minimum Data Set for Soil Quality Assessment of Typical Salt-Affected Farmland in the Coastal Reclamation Area. Soil and Tillage Research, 128, 137-148. https://doi.org/10.1016/j.still.2012.11.007

[81] Karlen, D.L., Wienhold, B.J., Kang, S., Zobeck, T.M. and Andrews, S.S. (2011) Indices for Soil Management Decisions. In: Hatfield, J.L. and Sauer, T.J., Eds., Soil Management. Building a Stable Base for Agriculture, American Society of Agronomy and Soil Science Society of America, Madison, WI, 39-50.

https://doi.org/10.2136/2011.soilmanagement.c3

[82] Arévalo-Gardini, E., Canto, M., Alegre, J., Loli, O., Julca, A. and Baligar, V. (2015) Changes in Soil Physical and Chemical Properties in Long Term Improved Natural and Traditional Agroforestry Management Systems of Cacao Genotypes in Peruvian 
Amazon. PLoS ONE, 10, e0132147. https://doi.org/10.1371/journal.pone.0132147

[83] Takoutsing, B., Weber, J.C., Tchoundjeu, Z. and Shepherd, K. (2016) Soil Chemical Properties Dynamics as Affected by Land Use Change in the Humid Forest Zone of Cameroon. Agroforestry Systems, 90, 1089-1102.

https://doi.org/10.1007/s10457-015-9885-8

[84] Emami, H., Neyshabouri, M.R. and Shorafa, M. (2012) Relationships between Some Soil Quality Indicators in Different Agricultural Soils from Varamin, Iran. Journal of Agricultural Science and Technology, 14, 951-959.

[85] Govaerts, B., Sayre, K.D. and Deckers, J. (2006) A Minimum Data Set for Soil Quality Assessment of Wheat and Maize Cropping in the Highlands of Mexico. Soil and Tillage Research, 87, 163-174. https://doi.org/10.1016/j.still.2005.03.005

[86] Mandal, U.K., Warrington, D.N., Bhardwaj, A.K., Bar-Tal, A., Kautsky, L., Minz, D. and Levy, G.J. (2008) Evaluating Impact of Irrigation Water Quality on a Calcareous Clay Soil Using Principal Component Analysis. Geoderma, 144, 189-197. https://doi.org/10.1016/j.geoderma.2007.11.014

[87] Liska, A.J. and Perrin, R.K. (2011) Energy and Climate Implications for Agricultural Nutrient Use Efficiency. In: Clay, D.E. and Shanahan, J.F., Eds., GIS Applications in Agriculture, Vol. Two: Nutrient Management for Energy Efficiency, CRC Press, Boca Raton, 1-17.

[88] Acton, D.F. and Gregorich, L.J. (1995) The Health of Our Soils-Towards Sustainable Agriculture in Canada. Centre for Land and Biological Resources Research, Research Branch, Agriculture and Agri-Food Canada, Ottawa, 138.

https://doi.org/10.5962/bhl.title.58906

[89] Karlen, D.L., Mausbach, M.J., Doran, J.W., Cline, R.G., Harris, R.F. and Schuman, G.E. (1997) Soil Quality: A Concept, Definition, and Framework for Evaluation (A Guest Editorial). Soil Science Society of America Journal, 61, 4-10. https://doi.org/10.2136/sssaj1997.03615995006100010001x

[90] Mosier, A.R. (1998) Soil Processes and Global Change. Biology and Fertility of Soils, 27, 221-229. https://doi.org/10.1007/s003740050424

[91] Vance, G.F., Pierzynski, G.M. and Sims, J.T. (1994) Soil and Environmental Quality. Lewis Publishers, Boca Raton, FL.

[92] Bouma, J. (2014) Soil Science Contributions towards Sustainable Development Goals and Their Implementation: Linking Soil Functions with Ecosystem Services. Journal of Plant Nutrition and Soil Science, 177, 111-120. https://doi.org/10.1002/jpln.201300646

[93] Bouma, J., Keesstra, S. and Cerdà, A. (2017) The Importance of Soil Science to Understand and Remediate Land Degradation and Desertification Processes. 19th EGU General Assembly, EGU2017, Vienna, Austria, 23-28 April 2017, Article ID: 16112.

[94] Bouma, J., Van Ittersum, M.K., Stoorvogel, J.J., Batjes, N.H., Droogers, P. and Pulleman, M.M. (2017) Soil Capability: Exploring the Functional Potentials of Soils. In: Field, D.J., Morgan, C.L.S. and McBratney, A.B., Eds., Global Soil Security, Springer, Cham, 27-44. https://doi.org/10.1007/978-3-319-43394-3 3

[95] Fine, A.K., van Es, H.M. and Schindelbeck, R.R. (2017) Statistics, Scoring Functions, and Regional Analysis of a Comprehensive Soil Health Database. Soil Science Society of America Journal, 81, 589-601. https://doi.org/10.2136/sssaj2016.09.0286

[96] Magdoff, F. and Van Es, H. (2000) Building Soils for Better Crops. Sustainable Agriculture Network, Beltsville.

[97] Frost, P.S. (2017) Soil Health Characterization of Agricultural Land in Jharkhand. 
Cornell University, India. Thesis, Cornell University, Ithaca, NY.

[98] Granatstein, D. and Bezdicek, D.F. (1992) The Need for A Soil Quality Index: Local and Regional Perspectives. American Journal of Alternative Agriculture, 7, 12-16. https://doi.org/10.1017/S0889189300004380

[99] Romig, D.E., Garlynd, M.J., Harris, R.F. and Mcsweeney, K. (1995) How Farmers Assess Soil Health and Quality. Journal of Soil and Water Conservation, 50, 229-236.

[100] Andrews, S.S., Karlen, D.L. and Cambardella, C.A. (2004) The Soil Management Assessment Framework: A Quantitative Soil Quality Evaluation Method. Soil Science Society of America Journal, 68, 1945-1962. https://doi.org/10.2136/sssaj2004.1945

[101] Doran, J.W. and Parkin, T.B. (1994) Defining and Assessing Soil Quality. In: Doran, J.W., Coleman, D.C., Bezdicek, D.F. and Stewart, B.A., Eds., Defining Soil Quality for a Sustainable Environment, Vol. 35, The Soil Science Society of America, Inc., Madison, WI, 1-21. https://doi.org/10.2136/sssaspecpub35.c1 